\title{
For a World Without Boundaries: Connectivity Between Marine Tropical Ecosystems in Times of Change
}

\author{
Hannah S. Earp, Natalie Prinz, Maha J. Cziesielski, \\ and Mona Andskog
}

\begin{abstract}
Tropical mangrove forests, seagrass beds, and coral reefs are among the most diverse and productive ecosystems on Earth. Their evolution in dynamic, and ever-changing environments means they have developed a capacity to withstand and recover (i.e., are resilient) from disturbances caused by anthropogenic activities and climatic perturbations. Their resilience can be attributed, in part, to a range of cross-ecosystem interactions whereby one ecosystem creates favorable conditions for the maintenance of its neighbors. However, in recent decades, expanding human populations have augmented anthropogenic activities and driven changes in global climate, resulting in increased frequencies and intensities of disturbances to these ecosystems. Many contemporary environments are failing to regenerate following these disturbances and consequently, large-scale degradation and losses of ecosystems on the tropical seascape are being observed. This chapter reviews the wealth of available literature focused
\end{abstract}

H. S. Earp $(\bowtie)$

Faculty of Biology and Chemistry, University of Bremen,

Bremen, Germany

e-mail: hannahsearp@ hotmail.com

Leibniz Centre for Tropical Marine Research (ZMT), Bremen, Germany

School of Ocean Sciences, Bangor University, Menai Bridge, Wales, UK

N. Prinz $\cdot$ M. Andskog

Faculty of Biology and Chemistry, University of Bremen,

Bremen, Germany

Leibniz Centre for Tropical Marine Research (ZMT),

Bremen, Germany

e-mail: nprinz@uni-bremen.de; andskog.mona@gmail.com

M. J. Cziesielski

Red Sea Research Centre, King Abdullah University of Science and Technology, Thuwal, Kingdom of Saudi Arabia

e-mail:maha.olschowsky@kaust.edu.sa on the tropical marine seascape to investigate the degree of connectivity between its ecosystems and how crossecosystem interactions may be impacted by everincreasing anthropogenic activities and human-induced climate change. Furthermore, it investigates how disruption and/or loss of these cross-ecosystem interactions may impact the success of neighboring ecosystems and consequently, the highly-valued ecosystem services to which these ecosystems give rise. The findings from this review highlight the degree of connectivity between mangroves, seagrasses and coral reefs, and emphasizes the need for a holistic, seascape-wide research approach to successfully protect and preserve these critically important ecosystems and their associated services for future generations.

\section{Introduction}

Within the tropical zone, cartographically defined as the area between the Tropics of Cancer and Capricorn $\left(\sim 23.5^{\circ} \mathrm{N}\right.$ and S) (Gnanadesikan and Stouffer 2006), three ecologically distinct marine ecosystems; mangroves forests, seagrass beds and coral reefs, can be found (Fig. 1). These ecosystems have long been known for; their rich biodiversity, with coral reefs alone hosting 25\% of known marine species (McAllister 1995; Plaisance et al. 2011), their high levels of gross productivity (for coral reefs it is estimated at ca. $0.4-5.5 \mathrm{~kg} \mathrm{C}$ $\mathrm{m}^{-2}$ year $^{-1}$ (Douglas 2001)), which rival those of terrestrial ecosystems, and the array of ecosystem goods and services which they provide (Costanza et al. 1997). Across the landsea boundary, mangroves have an annual economic value of approximately US\$200,000-900,000 per square kilometer (UNEP-WCMC 2006), and their extent is closely correlated to the success of adjacent fisheries (Manson et al. 2005; Aburto-Oropeza et al. 2008). A step further into the ocean, nutrient cycling by seagrasses has been valued at US\$ 19,000 ha $^{-1}$ year $^{-1}$ (Costanza et al. 1997). Finally, in the most 

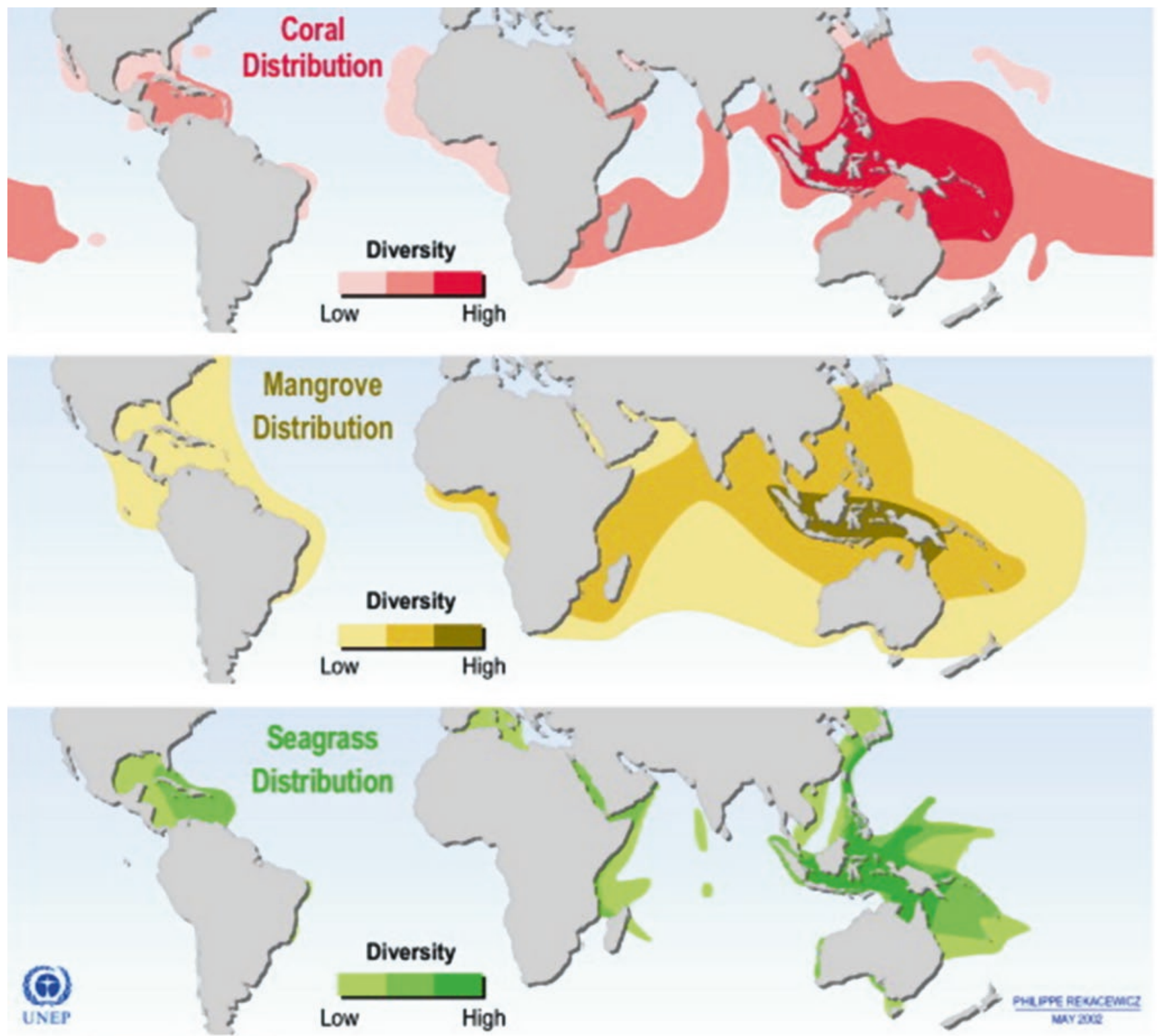

Source: UNEP-WCMC, 2001.

Fig. 1 Global distribution of coral, mangrove, and seagrass diversity. (Image created by Philippe Rekacewicz in May 2002 from data compiled by UNEP-WCMC, 2001. Reproduced from Jennerjahn 2012 with permission from Elsevier)

offshore habitat, coral reefs provide coastal protection, sustain fisheries, and drive tourism activities which are valued globally at US\$ 30 billion per annum (Stone 2007; Khan and Larrosa 2008).

Although these ecosystems can thrive in isolation (Parrish 1989), in regions where they occur together, the value of the services provided is enhanced. For example, each ecosystem alone provides a form of coastal protection (Koch et al. 2009), but together the three have been shown to supply more protection compared to any one ecosystem alone, or any combination of two ecosystems (Guannel et al. 2016). These services are, in part, the result of highly complex cross-ecosystem interactions occurring on physical, chemi- cal and biological levels (Ogden 1980; Nagelkerken 2009; Gillis et al. 2014). Early research, such as the mangrove 'outwelling' hypothesis proposed by Odum (1968), and Odum and Heald (1972) highlighted the importance of research beyond ecosystem boundaries. This hypothesis postulated that a fraction of organic matter, $\sim 50 \%$, produced by mangroves is exported to the coastal ocean (Dittmar et al. 2006), where it is either stored as carbon in marine sediments (Jennerjahn and Ittekkot 2002), or provides essential habitat and food resources to adjacent ecosystems including coral reefs (Bouillon et al. 2008; Granek et al. 2009). Since then, a wealth of studies have investigated individual connectivity pathways between tropical marine ecosystems. Biologically, 


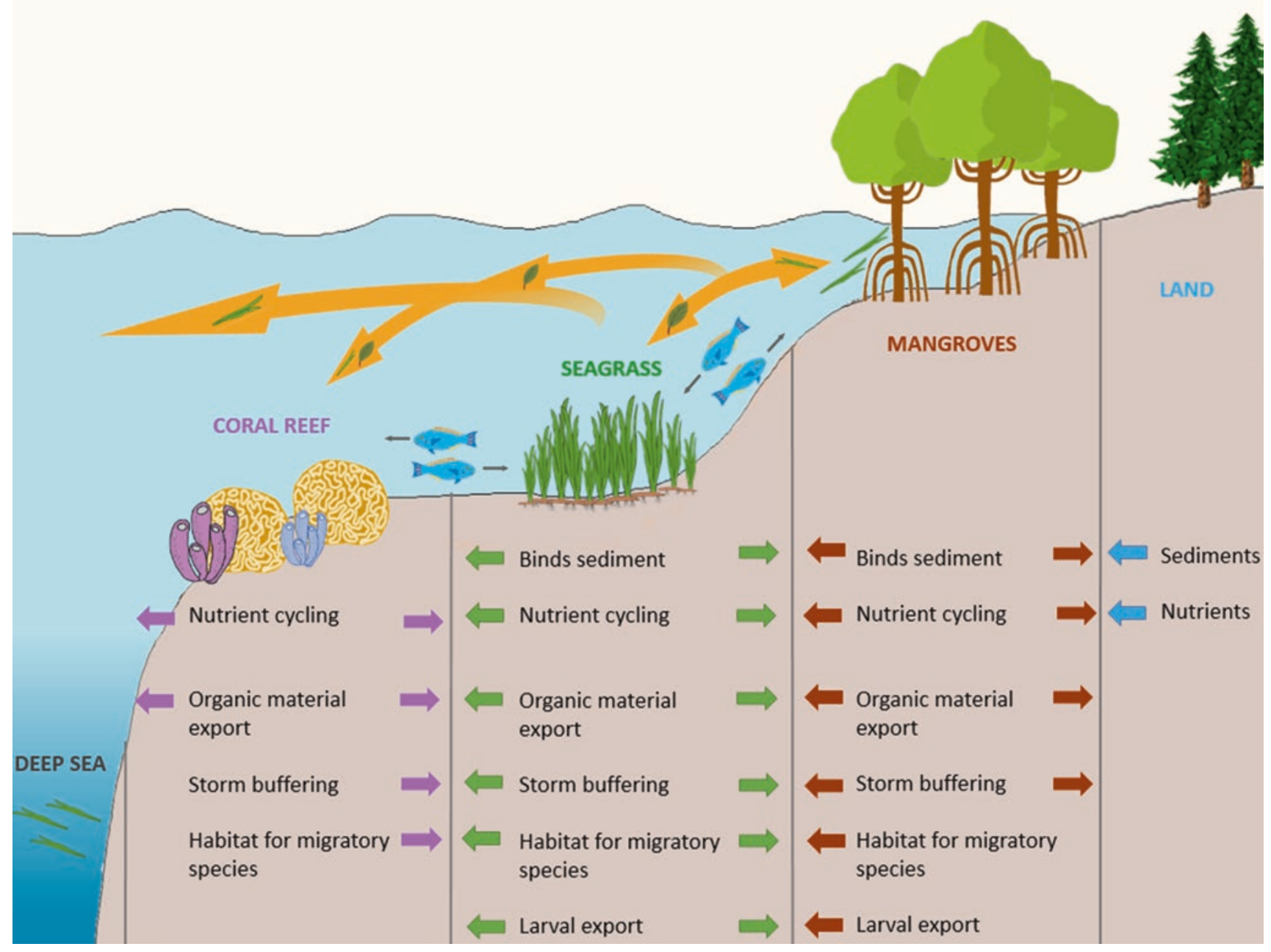

Fig. 2 Interdependencies of ecosystems along the tropical seascape. (Based on Moberg and Folke 1999; Heck et al. 2008; Berkström et al. 2012)

mobile organisms transition between ecosystems to forage, spawn, as part of seasonal migrations, or through ontogenesis (Parrish 1989; Cocheret de la Morinière et al. 2002; Mumby 2006). Water movement, including tidal regimes and currents further connect these systems by facilitating the exchange of organic matter, sediments, nutrients and pollutants (Fig. 2) (Grober-Dunsmore et al. 2009).

Although we are just beginning to uncover and understand the extent of these connectivity pathways, in most cases they are involved in creating optimal conditions for the successful maintenance of neighboring ecosystems. Coral reefs dissipate the energy of waves and currents, providing calm environments for seagrass and mangroves, whilst they in return stabilize the sediment and trap nutrients, creating the oligotrophic waters in which coral reefs thrive (Kitheka 1997; McGlathery et al. 2007; Mumby et al. 2011). Inevitably, the success of one ecosystem is directly linked to the success of the others, meaning the response of one ecosystem to change could result in profound consequences for neighboring systems (Grober-Dunsmore et al. 2009; Saunders et al. 2014).
Change is however, a natural attribute of global ecosystems (Alongi 2002), and tropical marine ecosystems have evolved under a regime of natural disturbances (Lamy et al. 2015). Consequently, they have developed a capacity to withstand and recover (i.e., are resilient) from periodic disruptions to their ecological equilibrium or 'steady-state' and readily regenerate (Connell 1997). However, in recent decades, disruptions in the form of anthropogenic activities (i.e., pollution and exploitation), human-induced climate change (i.e., temperature rise, ocean acidification, sea level rise, expansion of oxygen minimum zones, and severe weather events), and a combination of the two, have increased in intensity, duration, and extent (Vitousek et al. 1997). These disruptions pose significant challenges to tropical marine ecosystems and their associated cross-ecosystem interactions.

A lack of empirical data for tropical environments, compared to temperate regions, has resulted in conflicting predictions regarding the impact of future anthropogenic and climatic perturbations on tropical marine ecosystems (Alongi 2002). However, field studies have shown that many of these 
contemporary ecosystems are failing to regenerate following disturbances (Bellwood et al. 2004). The global loss and fragmentation of mangrove forests equates to a loss of ecosystem services worth US\$ 7.2 trillion year $^{-1}$ (Costanza et al. 2014). Other studies have noted significant global declines in seagrass areas, at rates of $110 \mathrm{~km}^{2}$ year ${ }^{-1}$ since 1980 , meaning at least $29 \%$ of their known areal extent has been lost (Green and Short 2003; Waycott et al. 2009; Short et al. 2014). In terms of coral reefs, estimates show $\sim 19 \%$ of the world's reefs have been lost (Wilkinson 2008), with $75 \%$ of present day reefs considered threatened when climatic and anthropogenic threats are combined (Burke et al. 2011), and 20\% of these are expected to disappear within 20 years (Wilkinson 2008). Furthermore, 55\% of coral reef fisheries in 49 island countries are considered as unsustainable (Newton et al. 2007). Overfishing threatens reef health by causing trophic cascades that may induce phase-shifts to macroalgal dominated environments, which subsequently impacts adjacent ecosystems and cross-ecosystem interactions (Jackson et al. 2001). Modelling studies compliment this research, revealing that impacts on one ecosystem can have profound impacts on neighboring ecosystems, and in turn, the ecosystem services they provide (Saunders et al. 2014).

Despite the overwhelming evidence that loss and degradation of these vital marine ecosystems will have far reaching ecological and economic impacts, significant gaps in our knowledge regarding the interconnectivity between these ecosystems remain (Duarte et al. 2008). Appealing to scientific research efforts, this review provides an overview of the impacts of augmenting anthropogenic activities, and human induced climate on the known interconnectivity pathways amongst tropical marine ecosystems, as opposed to each ecosystem in isolation. Sections "A Nutritious Ocean" and "An Empty Ocean" explore the response of cross-ecosystem interactions and ecosystems services to anthropogenic activities in the form of eutrophication and exploitation successively, whilst sections "A Warmer Ocean" and "A Sour Ocean" investigate their responses to ocean warming and acidification consecutively. Understanding the threats facing interdependencies between these ecosystems is suggested to be an opportunity for science to prevent large-scale losses of these critical environments in the face of disturbances in the years to come.

\section{A Nutritious Ocean}

Mangroves, seagrasses, and coral reefs are located either on, or near land masses (Spalding et al. 2001; Green and Short 2003), exposing them to local anthropogenic threats including periodic fertilizer runoff and sewage discharge, which are delivered to coastal waters (Fabricius 2005; Burke et al. 2011). This process, known as eutrophication, can stimulate phytoplankton blooms and algal growth in coastal ecosystems (McGlathery et al. 2007), which can lead to anoxia and toxic sulphide production due to increased microbial activity degrading this additional biomass (Flindt et al. 1999; Herbeck et al. 2014). These periodic enrichment events have become more prevalent within the last five decades, as annual global usage of nitrogen fertilizers has increased 14-fold, and is expected to increase even further (Matson et al. 1997; FAO 2016a).

Eutrophication can impact coastal ecosystems either directly, by affecting the fitness of organisms, or indirectly, by affecting processes within the ecosystem or altering the connectivity between ecosystems. In tropical regions, such as the Great Barrier Reef, seagrasses and mangroves are nutrient limited (Schaffelke et al. 2005). Therefore, the most common direct effect of nutrient enrichment is an increase in productivity and growth of these marine plants (Schaffelke et al. 2005), which alone is a positive effect. These ecosystems can therefore buffer eutrophication to a certain extent, and protect the oligotrophic waters of their vulnerable neighbors, coral reefs, from nutrient enrichment (Kitheka 1997; McGlathery et al. 2007). Indirect effects of eutrophication on marine plant communities are more commonplace, as excess nutrients also increase the productivity of other competing autotrophs, namely algae (Schaffelke and Klumpp 1998; McGlathery et al. 2007). In mangroves, there is little evidence of the direct effects of excess nutrients, however indirect links to mangrove dieback and damage do exist. The dieback of Avicennia marina in southern Australia was indirectly linked to eutrophication through the increased proliferation of the green macroalgae, Ulva sp., which smothered and killed the aerial roots of established mangroves, as well as smothering and inhibiting the growth of mangrove seedlings (Fig. 3) (Schaffelke et al. 2005). As mangroves have a high nutrient uptake capacity, they are also at risk of taking up herbicides and heavy metals which run-off agricultural land together with the nutrients. The build-up of these toxic substance has also been linked to mangrove dieback and damage in downstream estuarine habitats (Schaffelke et al. 2005).

Algal blooms may be even more detrimental for seagrasses as they are completely submerged in water and are highly dependent on light availability and water quality (McGlathery 2001). Light availability can be reduced by both biotic and abiotic factors. Biotic factors are primarily based on the abundance of phytoplankton, epiphytic algae, and seaweed wracks (Fig. 3) (McGlathery 2001; Herbeck et al. 2014; van Tussenbroek et al. 2017), whilst abiotic factors include increased particle loads from sewage effluent which settle on seagrass leaves or attenuate light within the water column (Herbeck et al. 2014). The increase in algal biomass will be followed by faster decomposition rates (Flindt et al. 1999), and therefore increased sulphide production in the sediment (Herbeck et al. 2014) (Fig. 3). Sulphide is toxic for seagrasses and leads to a decrease in shoot density, rhizome extension, and growth (Díaz-Almela et al. 2008; Herbeck et al. 2014; 


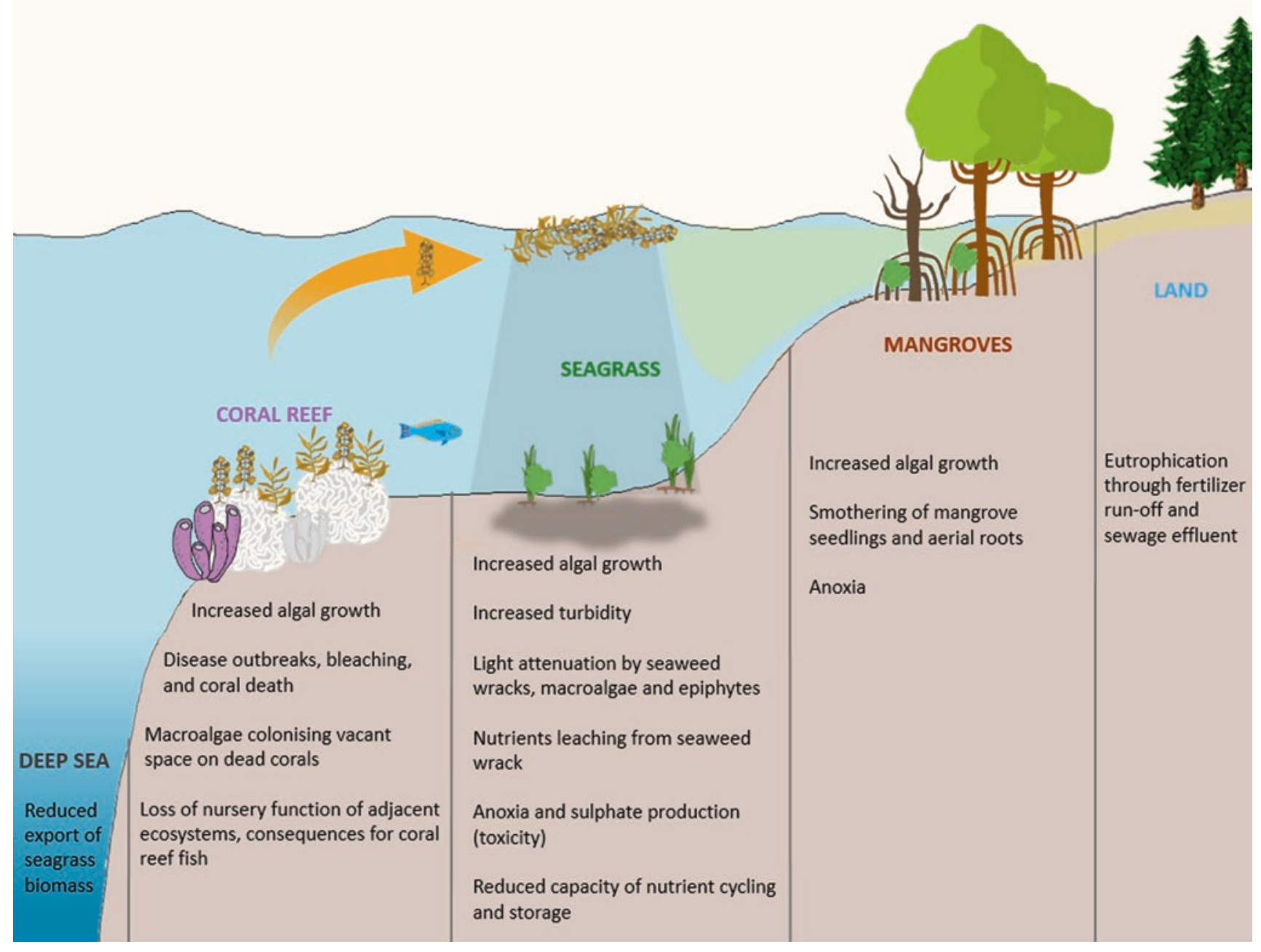

Fig. 3 Conceptual diagram detailing the possible consequences of eutrophication on each individual ecosystem as well as on the connectivity between them. Effects are not isolated within each system, but changes in one system may cause changes in others, either directly (e.g., transport of seaweed biomass) or indirectly (e.g., loss of ecosystem function such as nutrient retention or nursery areas). (Based on Moberg and Folke 1999; Heck et al. 2008; Berkström et al. 2012)
Maxwell et al. 2017). One way in which seagrasses counteract sulphide toxicity is by transporting oxygen from the leaves to the roots, thereby oxygenating the sediment (Borum et al. 2005). However, oxygen production is highly dependent on photosynthesis and light availability, which will be decreased during algal bloom conditions. This negative feedback loop can ultimately result in increased losses of seagrass and subsequent replacement by algae, which in turn stimulates further seagrass loss through elevated decomposition rates (Maxwell et al. 2017).

In regards to the connectivity between seagrass meadows and other ecosystems, we can expect multiple disruptions of important processes. For example, there are more than 50 records of seagrass shoots laying on the deep-sea floor $(>1000 \mathrm{~m})$, and there is evidence that seagrass detritus is an important subsidy to the deep-sea food web (Heck et al. 2008; Duarte and Krause-Jensen 2017). Seagrass has a relatively slow decomposition time compared to macroalgae (degradation rate constants range from 0.001 to $0.018 \mathrm{~d}^{-1}$ in seagrass and from 0.02 to $0.26 \mathrm{~d}^{-1}$ for Ulva spp.), enabling seagrass detritus to reach the deep-sea floor (Flindt et al. 1999; Heck et al. 2008). Algae are also exported from seagrass communities, but they have more labile organic matter than seagrasses and decompose before reaching the seafloor (Flindt et al. 1999; Heck et al. 2008). This important organic matter subsidy will be lost as seagrasses areas decline or shift to macroalgal meadows (Fig. 3). Furthermore, continuous, non-patchy seagrass beds with mangrove neighbors have a higher beta-diversity compared to patchy seagrass beds with greater distances to mangrove forests (Henderson et al. 2017). Proximity to mangroves is also positively related to parrotfish grazing of seagrass, which is crucial for the removal of epiphytes and leaf turnover (Swindells et al. 2017). We can expect that fragmentation, patchiness, and seagrass loss will further increase the distance to nearby mangroves and thereby affect these important ecosystem 
processes and diversity (Fig. 3). Furthermore, a recent study found that the prevalence of coral disease was $50 \%$ less on reefs with adjacent seagrass meadows, compared to reefs without (Lamb et al. 2017). Coral tissue mortality caused by bleaching and sedimentation was also significantly less on reefs with neighboring seagrass beds (Lamb et al. 2017). This is due to the role seagrasses play in filtering our pathogenic bacteria, and thus, in the face of continued sewage outflow in some regions, we can expect elevated bacterial and disease prevalence on neighboring coral reefs (Lamb et al. 2017) (Fig. 3). However, in other regions, seagrass meadow functions are not as vulnerable or important to ecosystem connectivity. In Brazil, evidence shows that macroalgal beds serve as a better nursery area for juvenile fish than adjacent seagrass beds, and that these seagrass beds had much lower juvenile fish abundances compared similar beds in the IndoPacific or Caribbean (Eggertsen et al. 2017). That being said, the negative effects of eutrophication across the rest of the world far outweigh this sole positive scenario.

Eutrophication of coral reefs environments, can promote phytoplankton blooms and thereby increase developmental success of the coral-consuming crown-of-thorns starfish (Acanthaster planci) larvae, which feed on phytoplankton (Fabricius et al. 2010; De'ath et al. 2012). Nutrient enrichment can also, as previously mentioned, enhance the growth and productivity of macroalgae (Schaffelke and Klumpp 1998). Once established on a coral reef, macroalgae may continue to proliferate if nutrients are available and herbivory is limited. Ultimately, this can result in a phase-shift (Lapointe 1997; McCook 1999) (Fig. 3). In the case of some South Pacific islands, the range and abundance of two native macroalgal species, Turbinaria ornata and Sargassum pacificum, have increased noticeably throughout the reefs since the 1980's (Payri and Naim 1982; Stewart 2008). These algae are primarily found on dead patches of corals on top of Porites heads, where they form dense aggregations (Stewart 2006). High swells frequently remove these macroalgae from their substrate, resulting in masses of floating algae which aggregate in currents to form large compact seaweed wracks (Zubia et al. 2015). These wracks are also seen as communities of drift algae such as Sargassum fluitans and Sargassum natans in the Caribbean. However, when exceptionally large blooms of these wracks reach nearby ecosystems such as seagrasses, they eutrophicate them through decomposition, reduction of light availability, increased hypoxia/anoxia, and reduction of $\mathrm{pH}$ (van Tussenbroek et al. 2017) (Fig. 3). We can therefore expect that these wracks stimulate algal growth inside the meadows, leading to seagrass loss, and inhibiting seagrass recovery (van Tussenbroek et al. 2017).

To summarize the effects of eutrophication on ecosystems within the tropical seascape, the effects on mangroves are not well documented, probably because they have a large capac- ity to absorb nutrients and are not dependent on water clarity to survive. Seagrass meadows can also buffer nutrient enrichment, but may be more vulnerable than mangroves as they are completely submerged and their survival depends on light availability. The greatest impacts of eutrophication are seen on coral reefs, which are the most vulnerable to excess nutrients, but may not be as exposed when seagrass meadows and mangrove forest are in the vicinity. With a loss of ecosystem functions in these ecosystems as a result of nutrient enrichment, we can expect that they will no longer be able to provide important services for each other, such as; nursery grounds, habitats, feeding grounds for mobile fauna, nutrient and sediment retention, and export of biomass (Fig. 3).

Nutrients and herbivory are two well-connected concepts in marine ecosystems, and in most cases, phase-shifts are not attributed to one or the other but rather a combination of the two (Adam et al. 2015). That is, eutrophication by itself is rarely the only reason why a system experiences algal blooms, as it is also highly dependent on grazing pressure from consumers (Hughes 1994). The health of these ecosystems is therefore not only dependent on what we add to them, but also what we remove, through the harvesting mangroves, corals, fish, and invertebrates.

\section{An Empty Ocean}

Human existence is directly and indirectly dependent on marine ecosystems (Halpern et al. 2008). In the tropics, millions of people rely directly on marine ecosystems to harvest food (e.g., fishes, clams, crabs) and raw materials (e.g., timber, curio artefacts, medicinal products), either for subsistence purposes, or for their livelihood (Hoegh-Guldberg 2014). As a consequence, these ecosystems are experiencing accelerating losses of biodiversity with largely unknown consequences (Worm et al. 2006). With over 1.3 billion people residing along tropical coastlines, primarily in developing countries (Sale et al. 2014), it is important to understand the impacts of harvesting activities within the tropical seascape, and its subsequent consequences for ecosystem services upon which so many people rely. This section will investigate the impact of mangrove harvesting for raw materials and the impact of fishing on the functioning and connectivity amongst tropical marine ecosystems.

Mangrove use by humans has a long history, extending back over 7000 years (Spalding et al. 2010; Tomlinson 2016), as a diverse array of goods can be harvested from them, including; tannins, honey, medicinal products, thatch, timber, and firewood (Hamilton and Snedaker 1984; Ellison 1994; Kathiresan and Bingham 2001; Spalding et al. 2010). The physical properties of mangroves differ amongst species; Rhizophora is most widely harvested due to its hard, dense, easily-splitting wood which makes it an ideal material 
for poles, firewood, and more recently wood-chips (for conversion to rayon), whilst Xylocarpus is more suitable for furniture/carving, and Aviennia is considered too soft to have any real harvesting value (Ewel et al. 1998). As a result of expanding human populations in recent decades, anthropogenic activities and our exploitation of these ecosystems has resulted in large-scale degradation and destruction of mangroves forests (Kathiresan and Bingham 2001; Spalding et al. 2010). Monospecific stands are exceptionally threatened by harvesting (Ewel et al. 1998), and when coupled with forest clearance to make way for development, vast areas of mangrove are being removed. It is estimated that one quarter of original mangrove cover $\left(>200,000 \mathrm{~km}^{2}\right)$, has been lost due to human activities, at a rate of $0.66-2 \%$ per annum (Duke et al. 2007; Spalding et al. 2010). This exceeds the loss rates reported for other threatened ecosystems (Stone 2007; Kathiresan 2008). For instance, of coral reefs, $10 \%$ have already been lost (Wilkinson 1992) and rainforests are lost at a rate of $0.8 \%$ per annum (Valiela et al. 2001). Consequently, mangroves are considered critically endangered or approaching extinction in 26 of the 120 countries in which they exist (Kathiresan 2008). Clearance and fragmentation of mangroves is of global concern due to its impact on ecosystem services like coastal protection, sediment trapping, nutrient cycling, and loss of habitats for commercially important species.

Mangroves provide coastal protection by mitigating the impact of tidal surges and waves caused by hurricanes and tsunamis (Duke et al. 2007). Estimates show that per kilometer of mangrove width, surges reduce in height by $5-50 \mathrm{~cm}$, and surface wind waves reduce by up to $75 \%$ (McIvor et al. 2012). During the super cyclone, which hit Orissa (India) in 1999, mangroves significantly reduced the number of deaths and damage to property (Badola and Hussain 2005). Evidence from the Indian Ocean tsunami in December 2004 showed that villages in India with mangrove buffers were damaged to a lesser extent compared to nearby villages with no mangroves (Kathiresan and Rajendran 2005; Vermaat and Thampanya 2006). The degree of protection provided by mangroves is attributed to several factors: forest width and slope, tree and root density, and tree height (Alongi 2002). Yet in many regions, clear-cutting and felling of mangroves significantly reduces the forest width as well as tree and root densities, and consequently lessenes the buffering capacity of mangrove ecosystems to the threats posed by hurricanes and tsunamis (Ellison 1994; Kathiresan and Bingham 2001; Spalding et al. 2010). This buffering capacity is cited as one of the most severely undervalued ecosystem services provided by mangroves (Barbier et al. 2011). More recently, studies have shown that the value of this service is augmented at sites where other foreshore ecosystems (i.e., seagrasses and coral reefs) are present. Guannel et al. (2016) concluded that mangroves in combination with a second foreshore ecosystem attenuate significantly more wave energy compared to any one ecosystem alone.

Sediment trapping and nutrient cycling pathways further connect mangroves to adjacent ecosystems (Ewel et al. 1998). Riverine transport and terrestrial runoff are important pathways to coastal environments and provide loads rich in sediments, nutrients, organic matter, and at times, pollutants, to coastal environments (Ramos et al. 2004). These terrestrially derived components are caught and slowed by the complex aerial root structure of mangroves, and become immobilized and sequestered within mangrove systems before they reach the clear, nutrient-limited waters of often adjacent seagrass and coral reefs (Morell and Corredor 1993; Valiela and Cole 2002). On Pohnpei (Federal States of Micronesia), reduction of forest width to make way for a road, led to the death of the remaining downstream mangroves which could not withstand the increased sediment loads that buried lenticels on pneumatophores, prop roots and young stems (Ewel et al. 1998). In regions where seagrass beds and coral reefs neighbor mangroves, loss and degradation of the mangrove forest due to harvesting activities can be seen to reduce sediment and nutrient trapping capacities, thus increasing the risk of sedimentation and eutrophication (see section "A Nutritious Ocean" for a review) in neighboring ecosystems. Despite several mentions of the important role mangroves play in protecting adjacent systems from sedimentation (Morell and Corredor 1993; Valiela and Cole 2002; Schaffelke et al. 2005), limited case studies exist showing the impact of mangrove harvesting on sedimentation of adjacent ecosystems.

In terms of carbon, mangroves have a dual capacity as both a sink of atmospheric $\mathrm{CO}_{2}$, and a source of oceanic carbon (Singh et al. 2005; Duke et al. 2007). Their high levels of productivity, which reached $26.70 \mathrm{t} \mathrm{ha}^{-1}$ year $^{-1}$ for Rizophora apiculata in Thailand (Christensen 1978), shows that their role in atmospheric $\mathrm{CO}_{2}$ assimilation to build biomass is of considerable importance (Spalding et al. 2010). However, it is hypothesized that net primary production of mangroves may be in excess of the carbon utilized in the system, consequently an estimated $20-30 \%$ is 'outwelled' to adjacent ecosystems (Bouillon et al. 2008; Granek et al. 2009), corresponding well to the $50 \%$ organic matter export estimate proposed by Dittmar et al. (2006). Although accurate quantification of the mangrove carbon budget remains limited (Bouillon et al. 2008; Alongi 2009), research has shown that clearing of mangroves could result in carbon emissions of up to $112-392 \mathrm{Mg} \mathrm{ha}^{-1}$ (Donato et al. 2011). These emissions would significantly influence global $\mathrm{CO}_{2}$ concentrations, which in turn drive climate change (see sections "A Warmer Ocean" and "A Sour Ocean" for reviews). Although their impact on carbon export to the coastal ocean remains unknown (Donato et al. 2011), what is known is that alterations to these fluxes could impact habitats and food resources 
for organisms which depend upon them, e.g., marine fishes and invertebrates.

Marine organisms including fishes and invertebrates have long been consumed by humans, with the earliest evidence extending back some 140,000 years to South Africa where shellfish and shallow-water fishes were consumed (Marean et al. 2007). Yet the development of fishing equipment is believed to have arisen 40,000 years later, based upon the oldest known fishing hooks found in East Timor (O'Connor et al. 2011). Since then, the evolution of fishing gears and vessels have supported a transition from small-scale subsistence fishing to modern-day commercial fishing, making seafood one of the most traded food commodities worldwide (FAO 2016b). Fishing is now considered to be the most widespread, unsustainable human impact on the oceans (Pauly et al. 2002; Halpern et al. 2008; Ricard et al. 2012), with $31.4 \%$ of fish stocks estimated to be fished at biologically unsustainable levels and therefore overfished in 2016 (FAO 2016b). More recently, the Food and Agricultural Organization of the United Nations (FAO) estimated that $89 \%$ of global fish stocks are exploited or overexploited (Zhou 2017).

On tropical coasts, fishing occurs at both subsistence and commercial levels, and targets an array of vertebrate (i.e., fishes such as snapper, parrotfish and grouper), and invertebrate (e.g., penaeid shrimp and mud crab) species. Many of these target species are considered 'mobile links' (Moberg and Folke 1999) due to the roles they play in connecting ecosystems across the tropical seascape through diel, seasonal and/or ontogenetic migrations (Parrish 1989; Cocheret de la Morinière et al. 2002; Mumby 2006). The larvae of the grey snapper (Lutjanus griseus) migrate towards their nursery area among the mangroves where they develop into juveniles, which later migrate to seagrass beds, and finally to coral reefs as adults, where they reproduce and the cycle repeats (Fig. 4) (Luo et al. 2009). Penaeid prawns also undergo a number of habitat shifts during their development, with the eggs released by adults on offshore waters undergoing two post-larval stages before they migrate to mangrove areas as juveniles. Late stage juveniles then move towards alternative habitats such as seagrasses before they transfer to their offshore adult habitat (Fig. 5) (Robertson and Duke 1987). Several studies have indicated that the abundance and diversity of fish communities in particular, are higher in regions where three tropical ecosystems were in close proximity, compared to those where they were a significant distance apart (Unsworth et al. 2008). The transition of organisms is not only a biological link between tropical ecosystems, it also results in a substantial transfer of organic matter, nutrients, and energy across ecosystems (Deegan 1993). It can therefore be postulated that the exploitation of certain species, would have knock-on effects for connectivity pathways among tropical marine ecosystems.
Gulf menhaden (Brevoortia patronus), small euryhaline clupeid fish found in the waters of the Gulf of Mexico, play an important role in exporting nutrients and energy between estuaries and offshore waters (Deegan 1993). They feed on phytoplankton and detritus and are in turn an important prey item for larger predatory fishes. They also support the second largest commercial fishery (by weight) in North America (Vaughan et al. 2007). When combined, their ecological and economic values mean this species, along with other Brevoortia species have been described as "the most important fish in the sea" (Franklin 2007). Although not currently considered overfished, exploitation of this species correlates to reduced production of larger pelagic fishes, and may lead to considerable effects on the trophic structure of ecosystems in the Gulf of Mexico (Robinson et al. 2015). Further research is essential to understand the impact of harvesting $B$. patronus on nutrient and energy export to adjacent systems. However, it can be seen that the exploitation of organisms with key ecological roles could have adverse effects on resource transfer among ecosystems and trophic levels. This theory could be applied to multiple exploited organisms transitioning between tropical ecosystems, however, research into the ecological roles of many of these organisms remains, at present, uninvestigated, thus the impact of their exploitation unknown.

One organism, whose role is known, and of vital importance to the health of coral reefs is the Caribbean rainbow parrotfish (Scarus guacamaia). Adults of this species play a pivotal role in regulating algal cover on reefs, and consequently preventing phase-shifts (Heenan and Williams 2013). There is evidence that the success of this species is dependent on the success of nearby mangroves. The juveniles of $S$. guacamaia are dependent on mangroves as nursery areas, and in Belizean coral reefs it was found that the density of adult parrotfish was significantly higher in mangrove-rich regions compared to mangrove-scarce regions (Mumby et al. 2004). Similar findings were made in Aruba, where recruitment of juvenile parrotfish from mangroves to coral reefs was dependent on the maximum distance $(10 \mathrm{~km})$ between these two habitats. S. guacamaia were therefore not be able to be recruited to coral reefs situated at a greater distance from mangroves (Dorenbosch et al. 2006). Coral reefs with adjacent mangrove nurseries exhibit increased parrotfish grazing (Mumby et al. 2007), and are consequently considered more resilient to perturbations. However, parrotfish are highly sensitive to exploitation, and several species including $S$. guacamaia are currently classified by the International Union for the Conservation of Nature as 'near threatened'. Exploited populations can only maintain $5 \%$ of a reef in a permanently grazed state compared to $40 \%$ in unexploited populations (Mumby 2006), which has implications concerning increased algal proliferation and its effect on adjacent ecosystems (see section "A Nutritious Ocean" 


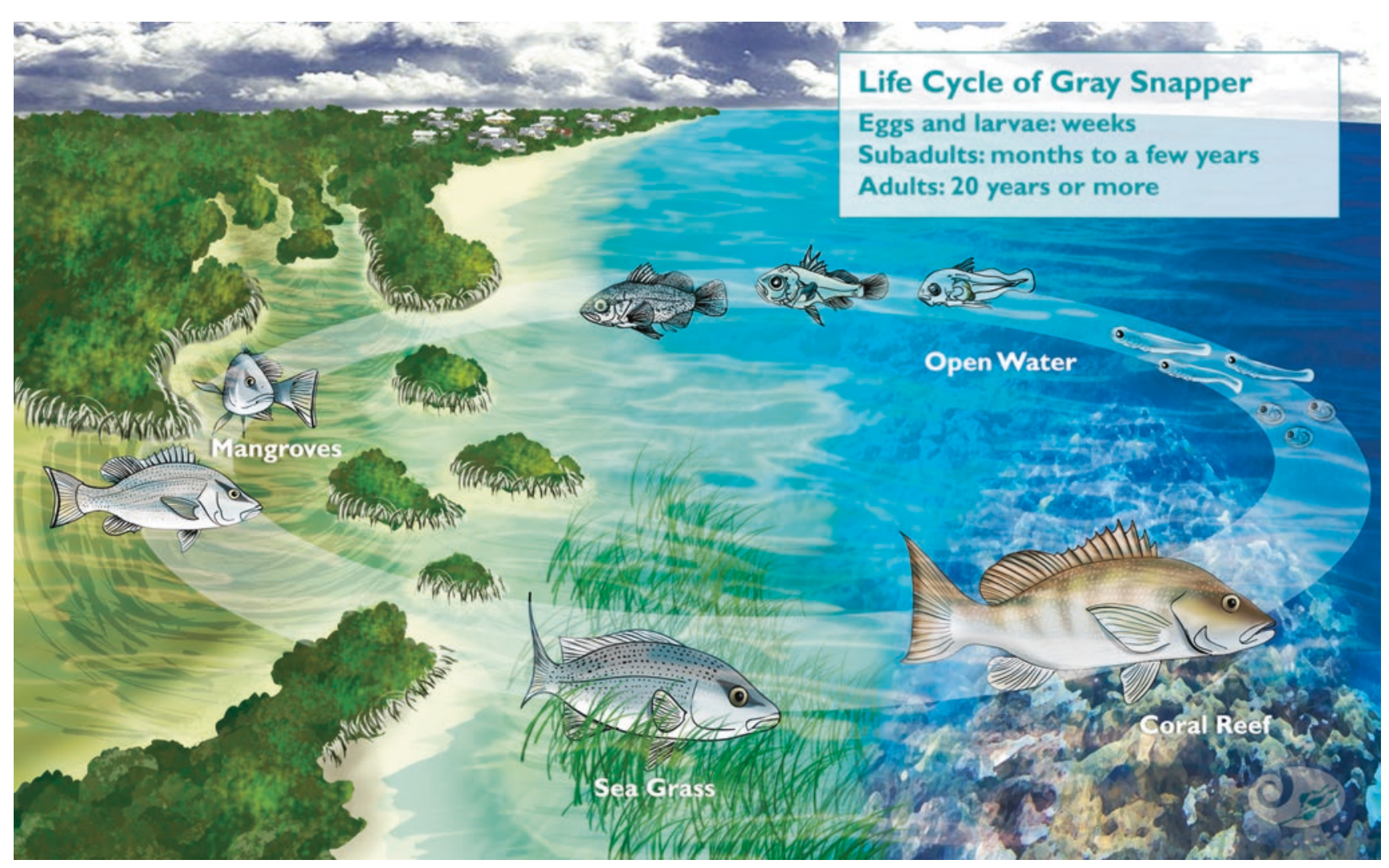

Fig. 4 The grey snapper uses many habitats throughout its life. Open water, mangroves, seagrass and coral reefs are important for the growth and survival during different stages of this fish. Art by Ryan Kleiner. (Reproduced from www.piscoweb.org, with permission from Kristen Milligan)

Fig. 5 The lifecycle of a penaeid prawn involves several habitats within the tropical seascape.

(Reproduced from www. csiropedia.csiro.au, with permission from Pamela Tyres)

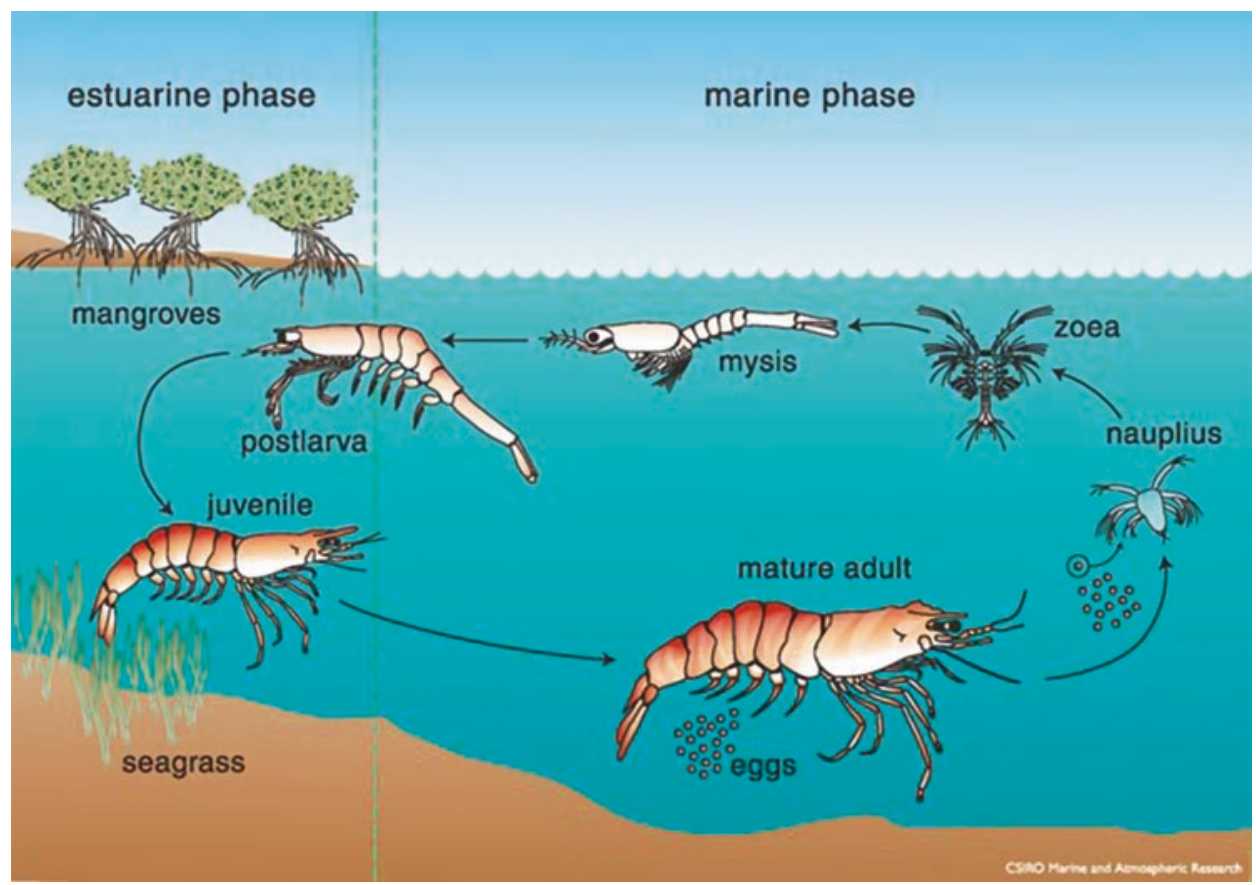

for a review). Bozec et al. (2016) discussed the trade-off between fisheries harvest and the resilience of coral reefs concluding that reefs will only remain resilient if $<10 \%$ of parrotfish (>30 cm in length) are harvested. Highlighting harvesting once more, the clear-cutting and fragmentation of mangroves reduces nursery areas, and increases the migration distance to reefs and thereby further threatening parrotfish populations. In the Caribbean, the combination of 
historical overexploitation of parrotfish and mangrove deforestation synergistically reduced herbivory and secondary production (Mumby et al. 2004). This highlights once again that research into the effect of exploitation on connectivity between tropical ecosystems is limited, and that there is a need for seascape-wide and cross-disciplinary research in the tropics.

\section{A Warmer Ocean}

Anthropogenic activities have had demonstrated localized impacts in tropical marine ecosystems, however, anthropogenic-induced stress in the form of global climate change is having impacts on these ecosystems on a global scale. Climate change occurs in several forms, but one of the most studied is the increase of atmospheric and oceanic temperatures. These temperature elevations can be attributed to the post-industrialization increase in atmospheric carbon dioxide $\left(\mathrm{CO}_{2}\right)$, a greenhouse gas, which is responsible for trapping the Earth's outgoing radiation within the atmosphere, and consequently allowing the planet to warm. By the end of the century, global surface temperature is estimated to have increased by $4{ }^{\circ} \mathrm{C}$ (IPCC 2013). The ocean has been heating up by absorbing $90 \%$ of incoming solar radiation since 1971 (Riser et al. 2016). This temperature increase is not the only impact of global warming, a number of indirect impacts are also expected including; the melting of glaciers and ice sheets resulting in sea level rise, increased precipitation resulting in elevated terrestrial runoff, and increased frequency and intensity of storms (Knutson et al. 2010; Trenberth 2011; Godoy and De Lacerda 2015).

At present, the distribution of some mangroves and seagrass species is confined by minimum and maximum air and sea temperatures (Short et al. 2007; Bjork et al. 2008; Ward et al. 2016). For the mangroves and seagrass systems not living towards the edge of their tolerance limits, an increase in temperature could initially result in positive responses (Alongi 2015). However, once their tolerance limits are surpassed the consequences are severe. A decrease in productivity and growth leads to a shift in community composition, favoring those better adapted to cope with the elevated temperatures which could ultimately lead to the disappearance of mangrove and seagrasses species with low thermal tolerances (Pernetta 1993; Short et al. 2011). Furthermore, temperature increase has been shown to cause changes in reproduction patterns and altered metabolism (Short and Neckles 1999; Gilman et al. 2008; Yeragi and Yeragi 2014; Arunparasath and Gomathinayagam 2015). These examples highlight the direct consequences of elevated atmospheric and oceanic temperatures, however, some of the most threatening impacts come from the collateral impacts of climate change.
If sea level rises due to glacial melting, it will not only result in changes to flooding duration and frequency, but also of salinity. Although mangroves are sensitive to such changes (Friess et al. 2012; Ward et al. 2016), they also exhibit exceptional resilience through their ability to actively modify their environment and migrate both inland and seawards (Fig. 6) (Krauss et al. 2014; Ward et al. 2016). Roots of mangrove trees trap sediment, allowing it to settle in the surrounding area. However, the ability of mangrove forests to respond to sea level rise will depend on sediment type and, importantly, the rate of sediment accretion (Ward et al. 2016). If sedimentation rates remain higher than the rate of sea level rise, then mangrove forests will respond by raising the seafloor and progressively moving inland (Alongi 2008; Godoy and De Lacerda 2015; Lovelock et al. 2015). By contrast, if sea level rise exceeds the sedimentation rate, then the forest will drown (Godoy and De Lacerda 2015; Ward et al. 2016).

The exceptional migratory capabilities of mangroves have enabled some forests to, contrary to what one might expect, have a positive response to climate change scenarios. Due to changes in global temperature regimes, mangroves are expanding their inland and poleward limits. The decreases in cold and arid conditions are enabling mangrove expansion into new territories (Godoy and De Lacerda 2015). Whilst the polar shift of mangrove forests essentially represents a re-distribution but potential survival of the ecosystem as a whole, inland migration may have severe impacts on other ecosystems, such as seagrass meadows, begging the question: will the survival of mangrove vegetation come at the cost of other ecosystems, or will these ecosystems also adapt by migrating?

Although also having distributional limits defined by sea and air temperatures, seagrass meadows can be seen as more sensitive than mangroves due to the fact they are exposed to elevated temperatures during the day, and can be subject to desiccation during low tides and consequently high ultraviolet and photosynthetically active radiation (Dawson and Dennison 1996; Durako and Kunzelman 2002; Campbell et al. 2007). Whilst direct impacts of temperature increase on seagrasses are similar to mangroves, changes in the carbon balance have been observed as an additional consequence. Carbon balances, particularly in the substrate, are affected by the increase in photosynthesis, which initially has benefits, but also disadvantages as the increased labile carbon (a product of photosynthesis), is transferred to the substrate, and in turn may alter microbial communities important for the maintenance of soil nutrients (Cotner et al. 2004; Koch et al. 2007). Thus, increasing water temperature in seagrass meadows directly affects nutrient composition not only of the sediment, but also the water column.

However, similarly to mangroves, the collateral impacts of global warming will also have substantial impacts on seagrass meadows. Light, nutrients, and turbidity, which influ- 

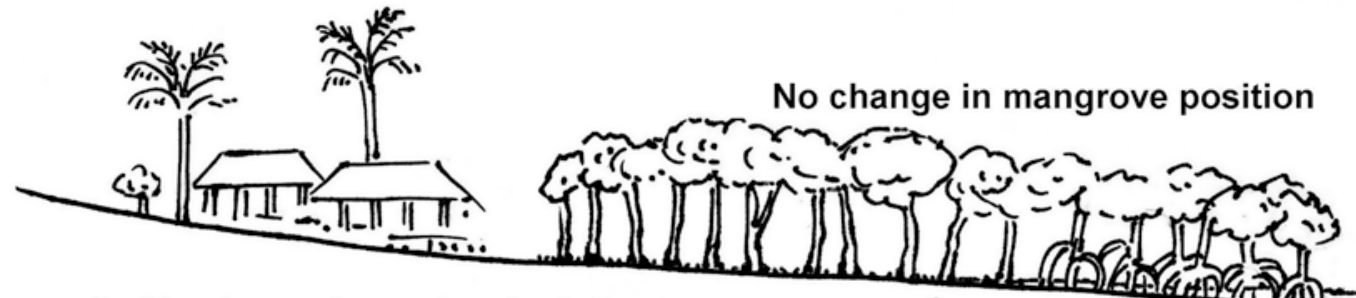

A. No change in sea level relative to mangrove surface.
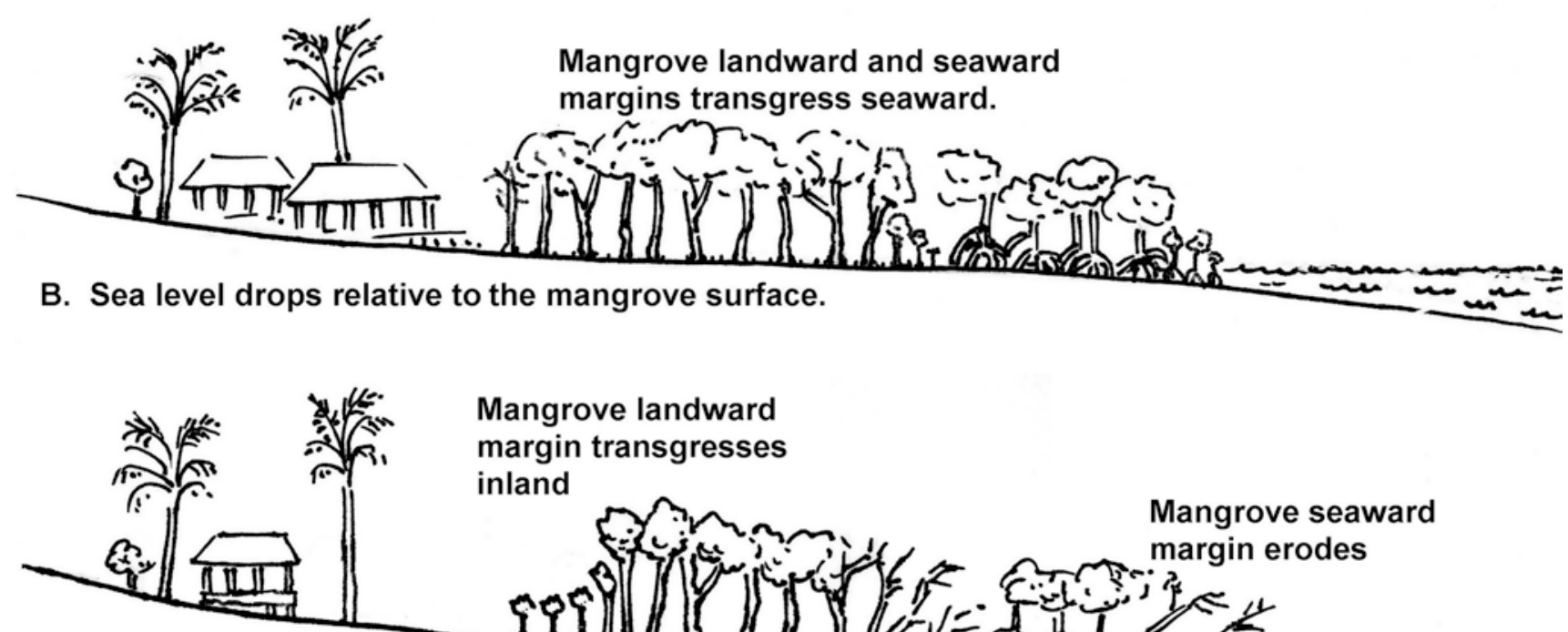

\section{Mangrove landward margin transgresses inland}

C. Sea level rises relative to the mangrove surface, and there are no obstacles to the mangrove's landward transgression.

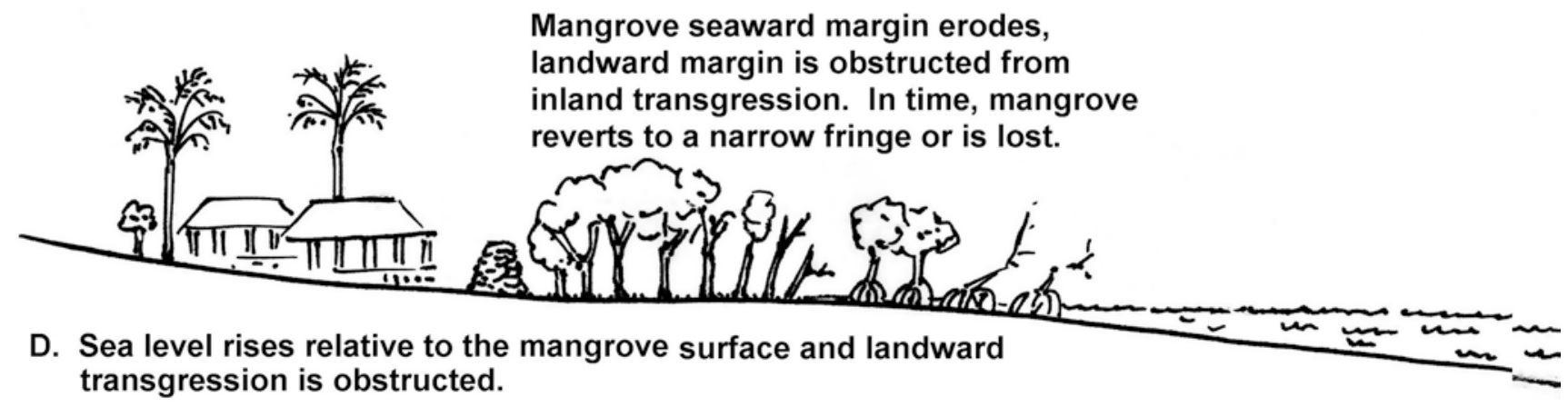

Fig. 6 Sea level rise generalized responses of mangroves. (a) Stable sea level where mangrove margins remain the same. (b) Sea level falls leading to a seaward shift of margins. (c) Sea level rises, no landward obstruction and high sedimentation rate allows margins to move

ence biochemical processes of seagrasses, will be altered due to changes in the atmosphere. Increased precipitation and sea level rise will result in changes in nutrient fluxes, sedimentation and salinity (Lee et al. 2007). Smothering of seagrasses due to sedimentation (potentially due to the loss of neighboring mangrove systems) and elevated sea levels, further limits sunlight to the meadows and consequently decreases their inwards. (d) Sea level rises, but landward obstruction and/or lack in sedimentation rate prevent migration of mangroves resulting in eroding margins and eventual loss. (Reproduced from Gilman et al. 2006 with permission from Eric Gilman)

productivity. Furthermore, climate change may also affect the frequency and strength of tropical storms, which carry their own set of consequences for seagrass meadows (Trenberth 2005), including sediment movement burying the seagrasses and increased turbulence caused by strong storms, that can last for long after the storm has passed could uproot and completely flatten the meadow (Bjork et al. 2008). 
Coral reefs act as natural barriers protecting the coastline from currents, waves and storms by dissipating their force and hence overall destructive impact (Moberg and Folke 1999). Calcite skeletons allow coral reefs to be robust structures that can withstand strong currents. However, studies have shown that increasing temperature, along with ocean acidification, are causing changes in skeletal growth and robustness (Tambutté et al. 2015). To understand how, one must first look at the physiology of corals.

Symbiodinium (i.e., dinoflagellates) residing in coral tissue provide the majority of the coral hosts' energy demands, allowing them to successfully thrive in oligotrophic waters (Yellowlees et al. 2008; Baker et al. 2015). The distribution of coral reefs is heavily limited by sea temperature, where the sensitivity to temperature stress depends on the physiological tolerance limits of both endosymbiotic partners (Putnam et al. 2012). When temperatures exceed tolerance limits, the most common response is the expulsion of symbionts from the tissue of the coral hosts, an event known as coral bleaching. The response to the loss of symbionts and their photosynthetic by-products, the largest energy source of corals, is a decline in coral productivity and skeletal growth (Langdon and Atkinson 2005; Pandolfi et al. 2011). Without Symbiodinium, corals can only survive for a limited time before the onset of tissue necrosis and ultimately their death. Hope for the survival of the reef exists in two forms; some species of symbionts are more thermotolerant than others, and if temperatures return to base-level the coral can recover by re-establishing symbiosis with Symbiodinium.

Some species of corals with different symbiont associations have managed to inhabit areas with extreme temperatures, highlighting their temperature resilient capacity (van Oppen et al. 2015). These symbionts have been accredited with a particularly important role in the overall thermal tolerance of corals, where temperature adapted symbiont clades can reduce the overall bleaching response (Berkelmans and van Oppen 2006; Sampayo et al. 2008; Howells et al. 2016). In recent years, advances in technology have made it possible to uncover some of the underlying mechanisms allowing for thermotolerance of corals and their symbionts, which potentially play important roles in their adaptation and acclimatization potential (Richier et al. 2008; DeSalvo et al. 2010; Kvitt et al. 2011; Bellantuono et al. 2012; Kenkel et al. 2013). By understanding these mechanisms it is hoped that we can aid corals in future response and survival, in light of global warming (Magris et al. 2015; van Oppen et al. 2015). Thus, it can be seen that temperature drastically impacts the survival of corals and if temperatures continue to increase as predicted, corals will struggle to recover from bleaching events and subsequently large-scale losses of coral reefs will be observed.

Whilst the direct effects of elevated temperatures on corals are frightening enough, they extend, as with seagrass and mangroves, into related atmospheric changes. Increased precipitation and sea level rise have two primary impacts, a decrease in salinity and alteration of nutrient fluxes. In the case of salinity, a decrease may actually directly influence thermotolerance of corals, whereas, recent studies have indicated that more saline environments could increase coral holobiont temperature resilience (Gegner et al. 2017). Whilst not directly impacting thermotolerance, eutrophication of the water column (as the result of declines in seagrass and mangroves areas) can cause imbalances in coral-symbiont relationships and ultimately leads to the breakdown of symbiosis (D'Angelo and Wiedenmann 2014). If the symbiotic relationship is already compromised by imbalances in nutrient exchange between the two partners, it is less likely to withstand additional temperature stress. Consequently, if corals undergo repeated long-term bleaching, calcification rates will be continuously affected. Since calcification is a costly process that requires a lot of energy, the lack of sufficient nutrients, due to symbiont absence, not only reduces growth but also increases the porosity of the skeleton (Tambutté et al. 2015). As storm frequency and intensity increase, coral skeletons will be less resilient to withstand turbulent waters, potentially leading to fractures and breaks, effectively destroying the reef. Thus, the existence of coral reefs is currently threatened not only by temperature increase, but also by most associated atmospheric changes which accompany global warming.

We can clearly see that the existence of mangroves, seagrass and coral reefs is currently threatened not only by temperature increase, but also by many associated changes in abiotic factors. However, the extent to which certain changes affect the ecosystem depends wholly on the system in question, as some are more resilient to certain abiotic stressors than others (Guannel et al. 2016). Sea level rise has shown contrasting impacts on mangrove, seagrasses and coral reefs, whereby seagrass showed the most resilience over longer periods of time (Albert et al. 2017). On the other hand, temperature increase of the water column is having the most detrimental effects on corals whose algal partners can escape suboptimal conditions, whilst the animal and its skeleton are left behind. Although mangroves, seagrass and coral reefs may respond differently to temperature and associated changes, the end point appears to be a decline in all three either through migration to new locations or permanent loss. As each ecosystem provides a service to help mitigate global warming impacts, the slow disappearance of one could increase the stress experienced by its neighbors. This is particularly important in terms of increased storm intensities and frequencies which have the potential to significantly impact sedimentation and nutrient enrichment, especially in regions where losses of ecosystems and their associated buffering, trapping, and absorbing capacities have occurred (Golbuu et al. 2003; Unsworth et al. 2012). Another global 
stressor that is tightly linked to temperature is ocean acidification. If temperature itself will have such extensive effects on tropical marine ecosystems, then the combination with ocean acidification will be unfathomable.

\section{A Sour Ocean}

Within the literature, ocean acidification has been closely coupled with the rise in atmospheric and oceanic temperatures, with all three being attributed primarily to rising levels of $\mathrm{CO}_{2}$ in the Earth's atmosphere (Caldeira and Wickett 2003; Hoegh-Guldberg and Bruno 2010). $\mathrm{CO}_{2}$ is not only a key player in climate change due to its ability to trap heat, but also a vital component of biological mechanisms (e.g., photosynthesis), which are important in sustaining life. The oceans play an important role in the global carbon cycle, acting as a 'carbon sink' by taking up about one third of $\mathrm{CO}_{2}$ from the atmosphere and transporting it around the globe (Le Quéré et al. 2013). The acidification of our oceans alters ocean chemistry, which poses significant challenges to these already threatened tropical marine ecosystems (Kroeker et al. 2010; Gaylord et al. 2015).

Since the industrial revolution our, on average, slightly alkaline ocean, with a $\mathrm{pH}$ of 8.2 , has experienced a decrease in $\mathrm{pH}$ of 0.1 units, which represents a $30 \%$ increase in acidity. The $\mathrm{pH}$ is predicted to drop a further 0.3 units by the end of the century (IPCC 2013). The trajectory towards an ocean with a lower $\mathrm{pH}$ will have both positive and negative consequences for marine organisms (Garrard et al. 2014). This was demonstrated by research conducted near oceanic vents, which emit large quantities of $\mathrm{CO}_{2}$ and consequently create areas of seabed with a lower than usual $\mathrm{pH}$ (Frankignoulle and Distèche 1984; Hall-Spencer et al. 2008; Fabricius et al. 2011; Scartazza et al. 2017). However, research on ocean acidification primarily focuses on the impacts to calcifying organisms such as corals, molluscs, echinoderms, crustaceans, coccolithophores, foraminifera, pteropods, and some species of algae. Increasing atmospheric $\mathrm{CO}_{2}$ alters the dissolved inorganic carbon distribution in seawater, reducing its $\mathrm{pH}$ and with it the availability of carbonate ions $\left(\mathrm{CO}_{3}{ }^{2-}\right)$ (Cohen and Holcomb 2009; Findlay et al. 2010). This impacts the energy-costly process of calcification as the rate at which calcifying organisms produce calcium carbonate $\left(\mathrm{CaCO}_{3}\right)$, is slowed to a point where rates of erosion exceed those of skeletal accretion (Cohen and Holcomb 2009; Gerber et al. 2014). In terms of non-calcifying species, acidification is believed to disturb acid-based (metabolic) physiology and impact their survival, growth, and reproduction (Fabry et al. 2008; Kroeker et al. 2010). Research into the response of non-calcifying organisms including jellyfish, fish, fleshy algae, and seagrasses to acidification is becoming more commonplace, yet, in the case of mangroves, the impacts remain vastly understudied (Guinotte and Fabry 2008; Kroeker et al. 2010).

Calcifying species appear to be the 'losers' in the case of a more acidic ocean, and exhibit a range of negative responses, especially when acidification is combined with other stressors (Hoegh-Guldberg et al. 2007; Fabricius et al. 2011). For coral calcification, studies have indicated that the extracellular calcifying medium is maintained at a higher $\mathrm{pH}$ than that of the surrounding seawater in order to facilitate $\mathrm{CaCO}_{3}$ precipitation (McCulloch et al. 2012). However, how changes in seawater $\mathrm{pH}$ would affect this internal biological control is currently unknown. More recently, studies have revealed that instead of decreasing their growth rate, corals are acclimatizing by decreasing their skeletal density and increasing their porosity (Tambutté et al. 2015). Although this morphological plasticity ensures slower, but continuous growth of the colony, it weakens the overall reef structure, making it more susceptible to damage resulting from anthropogenic or climatic perturbations (Hoegh-Guldberg et al. 2007). This weakening of skeletons also affects reef-building gastropods of the family Vermetidae, which provide coastal protection to neighboring ecosystems such as mangroves and seagrasses (Milazzo et al. 2014). The decreased reef resilience can be attributed to reduced structural complexity and coral species diversity (Anthony et al. 2011; Fabricius et al. 2011). A pH of 7.7 has been shown to cease reef development due to a shift in coral species dominance, away from structural corals (branching, foliose, and tabulate growth forms) towards massive growth forms such as Porites corals (Fabricius et al. 2011). These reductions in reef complexity can in turn impact the biodiversity of reef-associated species as well as trophic interactions, and other ecosystem processes (Raven et al. 2005; Kleypas et al. 2006).

For non-calcifying marine consumers, elevated oceanic $\mathrm{CO}_{2}$ and the accompanying change in $\mathrm{pH}$ will have negative effects as it will require additional energy for metabolic acid-based regulation (Pörtner 2008). Ocean acidification slows larval development in fishes, molluscs and echinoderms (Kurihara 2008; Miller et al. 2009; Dupont et al. 2010; Talmage and Gobler 2010; Dineshram et al. 2013; Gazeau et al. 2013). The early life stages of fish are impacted by a reduction of their oxygen consumption capacity and hence their activity, along with olfactory cues for predation, settlement, and reproduction (Munday et al. 2009). However, these highly mobile organisms have developed intra- or extracellular $\mathrm{pH}$ regulatory mechanisms that may aid them to be more resilient to ocean acidification (Kroeker et al. 2010). An additional option for fishes to escape a more acidic environment is finding refuge in seagrass meadows (Hendriks et al. 2014), and potentially mangrove roots (Chakraborty et al. 2013). 
Primary producers including seagrasses and macroalgae appear to be the winners in the face of elevated oceanic $\mathrm{CO}_{2}$ concentrations and lower seawater $\mathrm{pH}$. Increased $\mathrm{CO}_{2}$ concentrations in seawater are a resource for these primary producers (Palacios and Zimmerman 2007; Fabricius et al. 2011; Hepburn et al. 2011) which allow them to enhance their productivity and growth (Harley et al. 2012; Koch et al. 2013). Seagrasses are known to alter the carbonate chemistry in the water column, which is of particular importance in regions where they neighbor coral reef environments (Dorenbosch et al. 2005; Hendriks et al. 2014). In the Mediterranean, Posidonia oceanica diurnally modify the water column $\mathrm{pH}$ by as much as $0.2-0.7$ units through photosynthesis and respiration (Frankignoulle and Distèche 1984; Invers et al. 1997; Hall-Spencer et al. 2008; Scartazza et al. 2017), and a similar process is also exhibited by macroalgae dominated reef-tops (Russell et al. 2009). Additionally, ocean acidification results in decreased carbon to nitrogen $(\mathrm{C}: \mathrm{N})$ ratios in $P$. oceanica tissues, which increases shoot density, leaf proteins, and asparagine accumulation in the rhizomes (Scartazza et al. 2017). This in turn provides a positive contribution to associated food-webs given the nutritional quality of organic matter available for herbivores and consequently an increase in the grazing rate is observed (Kroeker et al. 2010; Arnold et al. 2012; Rossoll et al. 2012; Scartazza et al. 2017). However, the spatial scale of these processes, ranging from millimeters to entire water layers, must be kept in mind when extrapolating their impacts to an ecosystem extent (Hendriks et al. 2015).

This enhanced productivity of seagrass meadows is likely to contribute to enhanced productivity in neighboring coral reef ecosystems on the tropical seascape. Modelling studies suggests that calcification on coral reefs with seagrass neighbors may be up to $18 \%$ greater compared to reefs without neighboring seagrasses (Unsworth et al. 2012). Their role in enhancing calcification rates will continue and possibly even increase (Zimmerman et al. 1997), allowing coral and invertebrate communities to persist (Unsworth et al. 2012; Garrard et al. 2014). The term connectivity is primarily used in the context of ocean acidification to discuss the disruption to organismal reproduction, dispersal and hence, the connectivity of populations in a more acidic ocean (Cowen et al. 2006; Gerber et al. 2014). Ocean acidification appears to exhibit an especially strong capacity to drive ecological change and hence its impacts are not straight forward in the bigger picture (Gaylord et al. 2015). The coupled responses create a complex interplay among the physiological susceptibility of organisms to ocean acidification, the availability of resources, and the intensity of competition (Gaylord et al. 2015). Models suggest that a decreasing ocean $\mathrm{pH}$ will impose additional physiological stresses to the global distribution of species, narrowing the breadth of the thermal performance curve (Pörtner 2008). Ocean acidification effects would lead to smaller overall ranges, and ranges for which equatorward boundaries shift more dramatically towards poleward ones (Gaylord et al. 2015). How species will respond within the context of their communities is yet to be investigated. However, it is almost certain that many of the most striking consequences of acidification will arise through altered biotic interactions (Fabricius et al. 2011; Falkenberg et al. 2013; Kroeker et al. 2013; McCormick et al. 2013).

In summary, primary producers like seagrass beds are a crucial buffer zone of potential stressors for the calcifying fauna of coral reefs, with which interactions seem to be key for the resilience of many different species and even ecosystems in the face of environmental perturbations. With this in mind a more interconnected approach needs to be taken into consideration for tropical ecology under ocean acidification (Fabry et al. 2008; Garrard et al. 2014). Similar to Gaylord et al. (2015) and their argumentation that ocean acidification needs to be seen not only in the individual but ecosystem context, we argue that ecosystems need to be investigated in a connected manner. It is unequivocal that this issue requires global human action (Kennedy et al. 2013).

\section{Summary}

The evolution of mangroves, seagrasses, and coral reefs in ever-changing environments has allowed them to form highly-adapted, and for the most part, resilient ecosystems. This resilience, however, is often facilitated by their connectivity to adjacent ecosystems. But within one generation, anthropogenic activities and human-induced climate change have exerted such pressures on these connectivity pathways that a decline in ecosystem resilience and services has been observed. Consequently, places on Earth previously considered refugia for a range of species may cease to exist. Perhaps one of the most significant examples of these combined stressors on tropical marine ecosystems occurred in the Red Sea, where in the 1960s $98 \%$ of its coasts were considered to be "in practically virgin condition" (Ormond 1987). However, rapid development in this area, as a result of expansion in petroleum-based economies, meant the 'virgin' status of many regions was lost (Gladstone 2008). Over $75 \%$ of mangrove forests were degraded by activities including felling, cutting, sewage, root burial or overgrazing by camels (Gladstone 2008), and coral reefs, especially those by industrializing areas were impacted by dredging, sewage, and tourism (Gladstone 2008). Further to these threats, industrial trawling depleted economically important species (Gladstone 2008).

The underlying cause of many of these activities, both in the Red Sea and around the globe are: expanding populations, rapid urbanization, and weak governance, coupled with a lack of baseline information on tropical marine eco- 
systems, limited awareness of the consequences of human activities, and, most importantly, a lack of perspective regarding the connectivity among ecosystems on the tropical seascape (Duda and Sherman 2002). This review has highlighted the scale and importance of connectivity between tropical marine ecosystems, and investigated the impact of select anthropogenic activities and climatic perturbations on their associated connectivity pathways and ecosystem services. Only by progressing our understanding of these environments can the impact of human activities and changes in environmental conditions on nature be better elucidated. It is concluded that in order to effectively protect and preserve these critically important ecosystems and their associated services for future generations, we can no longer consider each ecosystem as a separate entity, and instead a holistic, seascape-wide approach is paramount. This means, the static, 'boundary-based' norm of scientific thinking must be overcome, and instead a more flexible, inter-ecosystem and interdisciplinary approach employed, which may, in turn, lead to strategies, which balance environmental change whilst allowing human subsistence to be ensured.

Acknowledgements The authors are grateful to constructive input by Mirco Wölfelschneider, Timothy Thomson and Dr. Siobhan Vye. Thanks also to Dr. Simon Jungblut for his continuous support and to two reviewers who contributed significantly to the final version of this chapter.

\section{Appendix}

This article is related to the YOUMARES 8 conference session no. 14: "Tropical Aquatic Ecosystems Across Time, Space and Disciplines". The original Call for Abstracts and the abstracts of the presentations within this session can be found in the appendix "Conference Sessions and Abstracts", chapter "8 Tropical Aquatic Ecosystems Across Time, Space and Disciplines", of this book.

\section{References}

Aburto-Oropeza O, Ezcurra E, Danemann G et al (2008) Mangroves in the Gulf of California increase fishery yields. Proc Natl Acad Sci USA 105:10456-10459. https://doi.org/10.1073/pnas.0804601105

Adam TC, Burkepile DE, Ruttenberg BI et al (2015) Herbivory and the resilience of Caribbean coral reefs: knowledge gaps and implications for management. Mar Ecol Prog Ser 520:1-20. https://doi. org/10.3354/meps 11170

Albert S, Saunders MI, Roelfsema CM et al (2017) Winners and losers as mangrove, coral and seagrass ecosystems respond to sea-level rise in Solomon Islands. Environ Res Lett 12(9):094009. https://doi. org/10.1088/1748-9326/aa7e68

Alongi DM (2002) Present state and future of the world's mangrove forests. Environ Conserv 29:331-349. https://doi.org/10.1017/ S0376892902000231
Alongi DM (2008) Mangrove forests: resilience, protection from tsunamis, and responses to global climate change. Estuar Coast Shelf Sci 76:1-13

Alongi DM (2009) The energetics of mangrove forests. Springer Science/Business Media BV, New York

Alongi DM (2015) The impact of climate change on mangrove forests. Curr Clim Chang Rep 1:30-39. https://doi.org/10.1007/ s40641-015-0002-x

Anthony KRN, Maynard JA, Diaz-Pulido G et al (2011) Ocean acidification and warming will lower coral reef resilience. Glob Chang Biol 17:1798-1808. https://doi.org/10.1111/j.1365-2486.2010.02364.x

Arnold TM, Mealey C, Leahey H et al (2012) Ocean acidification and the loss of phenolic substances in marine plants. PLoS ONE 7:e35107. https://doi.org/10.1371/journal.pone.0035107

Arunparasath A, Gomathinayagam M (2015) Reproductive phenology of true mangrove species in Pichavaram mangrove forests, Tamilnadu, India - a comparative account. J Environ Treat Tech 15:17-21

Badola R, Hussain SA (2005) Valuing ecosystem functions: an empirical study on the storm protection function of Bhitarkanika mangrove ecosystem, India. Environ Conserv 32:85-92. https://doi. org/10.1017/S0376892905001967

Baker DM, Freeman CJ, Knowlton N et al (2015) Productivity links morphology, symbiont specificity and bleaching in the evolution of Caribbean octocoral symbioses. ISME J 9:2620-2629. https://doi. org/10.1038/ismej.2015.71

Barbier EB, Hacker SD, Kennedy C et al (2011) The value of estuarine and coastal ecosystem services. Ecol Monogr 81:169-193. https:// doi.org/10.1890/10-1510.1

Bellantuono AJ, Granados-Cifuentes C, Miller DJ et al (2012) Coral thermal tolerance: tuning gene expression to resist thermal stress. PLoS ONE 7:e50685. https://doi.org/10.1371/journal.pone.0050685

Bellwood DR, Hughes TP, Folke C et al (2004) Confronting the coral reef crisis. Nature 429:827-833. https://doi.org/10.1038/ nature 02691

Berkelmans R, van Oppen MJ (2006) The role of zooxanthellae in the thermal tolerance of corals: a "nugget of hope" for coral reefs in an era of climate change. Proc R Soc B 273:2305-2312. https://doi. org/10.1098/rspb.2006.3567

Berkström C, Gullström M, Lindborg R et al (2012) Exploring "knowns" and "unknowns" in tropical seascape connectivity with insights from East African coral reefs. Estuar Coast Shelf Sci 107:1-21. https://doi.org/10.1016/j.ecss.2012.03.020

Bjork M, Short F, Mcleod E et al (2008) Managing seagrasses for resilience to climate change. IUCN, Gland. https://doi.org/10.1017/ CBO9781107415324.004

Borum J, Pedersen O, Greve TM et al (2005) The potential role of plant oxygen and sulphide dynamics in die-off events of the tropical seagrass, Thalassia testudinum. J Ecol 93:148-158. https://doi. org/10.1111/j.1365-2745.2004.00943.x

Bouillon S, Borges AV, Castañeda-Moya E et al (2008) Mangrove production and carbon sinks: a revision of global budget estimates. Glob Biogeochem Cycles 22:GB2013. https://doi. org/10.1029/2007GB003052

Bozec Y-M, O'Farrell S, Bruggemann JH et al (2016) Tradeoffs between fisheries harvest and the resilience of coral reefs. Proc Natl Acad Sci USA 113:4536-4541. https://doi.org/10.1073/ pnas. 1601529113

Burke L, Reytar K, Spalding MD et al (2011) Reefs at risk revisited. World Resources Institute, Washington, DC

Caldeira K, Wickett ME (2003) Oceanography: anthropogenic carbon and ocean $\mathrm{pH}$. Nature 425:365. https://doi.org/10.1038/425365a

Campbell PKE, Middleton EM, McMurtrey JE et al (2007) Assessment of vegetation stress using reflectance or fluorescence measurements. J Environ Qual 36:832-845. https://doi.org/10.2134/jeq2005.0396

Chakraborty S, Zaman S, Pramanick P et al (2013) Acidification of Sundarbans mangrove estuarine system. Discov Nat 6:14-20 
Christensen B (1978) Biomass and primary production of Rhizophora apiculata B1. in a mangrove in southern Thailand. Aquat Bot 4:4352. https://doi.org/10.1016/0304-3770(78)90005-0

Cocheret de la Morinière E, BJA P, Nagelkerken I et al (2002) Postsettlement life cycle migration patterns and habitat preference of coral reef fish that use seagrass and mangrove habitats as nurseries. Estuar Coast Shelf Sci 55:309-321. https://doi.org/10.1006/ ecss. 2001.0907

Cohen A, Holcomb M (2009) Why corals care about ocean acidification: uncovering the mechanism. Oceanography 22:118-127. https://doi.org/10.5670/oceanog.2009.102

Connell JH (1997) Disturbance and recovery of coral assemblages. Coral Reefs 16:S101-S113. https://doi.org/10.1007/s003380050246

Costanza R, Arge R, de Groot R et al (1997) The value of the world's ecosystem services and natural capital. Nature 387:253-260. https:// doi.org/10.1038/387253a0

Costanza R, de Groot R, Sutton P et al (2014) Changes in the global value of ecosystem services. Glob Environ Chang 26:152-158. https://doi.org/10.1016/j.gloenvcha.2014.04.002

Cotner JB, Suplee MW, Chen NW et al (2004) Nutrient, sulfur and carbon dynamics in a hypersaline lagoon. Estuar Coast Shelf Sci 59:639-652. https://doi.org/10.1016/j.ecss.2003.11.008

Cowen RK, Paris CB, Srinivasan A (2006) Scaling of connectivity in marine populations. Science 311:522-527. https://doi.org/10.1126/ science. 1122039

D'Angelo C, Wiedenmann J (2014) Impacts of nutrient enrichment on coral reefs: new perspectives and implications for coastal management and reef survival. Curr Opin Environ Sustain 7:82-93. https:// doi.org/10.1016/j.cosust.2013.11.029

Dawson SP, Dennison WC (1996) Effects of ultraviolet and photosynthetically active radiation on five seagrass species. Mar Biol 125:629-638. https://doi.org/10.1007/BF00349244

De'ath G, Fabricius KE, Sweatman H et al (2012) The 27-year decline of coral cover on the Great Barrier Reef and its causes. Proc Natl Acad Sci USA 109:17995-17999. https://doi.org/10.1073/ pnas. 1208909109

Deegan LA (1993) Nutrient and energy transport between estuaries and coastal marine ecosystems by fish migration. Can J Fish Aquat Sci 50:74-79. https://doi.org/10.1139/f93-009

DeSalvo MK, Sunagawa S, Fisher PL et al (2010) Coral host transcriptomic states are correlated with Symbiodinium genotypes. Mol Ecol 19:1174-1186. https://doi.org/10.1111/j.1365-294X.2010.04534.x

Díaz-Almela E, Marbà N, Álvarez E et al (2008) Benthic input rates predict seagrass (Posidonia oceanica) fish farm-induced decline. Mar Pollut Bull 56:1332-1342. https://doi.org/10.1016/j. marpolbul.2008.03.022

Dineshram R, Thiyagarajan V, Lane A et al (2013) Elevated $\mathrm{CO}_{2}$ alters larval proteome and its phosphorylation status in the commercial oyster, Crassostrea hongkongensis. Mar Biol 160:2189-2205. https://doi.org/10.1007/s00227-013-2176-x

Dittmar T, Hertkorn N, Kattner G et al (2006) Mangroves, a major source of dissolved organic carbon to the oceans. Glob Biogeochem Cycles 20:GB1012. https://doi.org/10.1029/2005GB002570

Donato DC, Kauffman JB, Murdiyarso D et al (2011) Mangroves among the most carbon-rich forests in the tropics. Nat Geosci 4:293-297. https://doi.org/10.1038/ngeo1123

Dorenbosch M, Grol MGG, Christianen MJA et al (2005) Indo-Pacific seagrass beds and mangroves contribute to fish density and diversity on adjacent coral reefs. Mar Ecol Prog Ser 302:63-76. https://doi. org/10.3354/meps302063

Dorenbosch M, Grol MGG, Nagelkerken I et al (2006) Seagrass beds and mangroves as potential nurseries for the threatened Indo-Pacific humphead wrasse, Cheilinus undulatus and Caribbean rainbow parrotfish, Scarus guacamaia. Biol Conserv 129:277-282. https://doi. org/10.1016/j.biocon.2005.10.032
Douglas AE (2001) The productivity of corals. Encyclopedia of life support systems 2. Developed under the Auspices of the UNESCO, Eolss Publishers, Paris, France, [http://www.eolss.net]

Duarte CM, Krause-Jensen D (2017) Export from seagrass meadows contributes to marine carbon sequestration. Front Mar Sci 4:13. https://doi.org/10.3389/fmars.2017.00013

Duarte CM, Borum J, Short FT et al (2008) Seagrass ecosystem: their global status and prospects. In: NVC P (ed) Aquatic ecosystems: trend and global prospects. Cambridge University Press, Cambridge, pp 281-294

Duda AM, Sherman K (2002) A new imperative for improving management of large marine ecosystems. Ocean Coast Manag 45:797-833. https://doi.org/10.1016/S0964-5691(02)00107-2

Duke NC, Meynecke J-O, Dittmann S et al (2007) A world without mangroves? Science 317:41b-42b. https://doi.org/10.1126/ science. $317.5834 .41 \mathrm{~b}$

Dupont S, Ortega-Martínez O, Thorndyke M (2010) Impact of near-future ocean acidification on echinoderms. Ecotoxicology 19:449-462

Durako MJ, Kunzelman JI (2002) Photosynthetic characteristics of Thalassia testudinum measured in situ by pulse-amplitude modulated (PAM) fluorometry: methodological and scale-based considerations. Aquat Bot 73:173-185. https://doi.org/10.1016/ S0304-3770(02)00020-7

Eggertsen L, Ferreira CEL, Fontoura L et al (2017) Seaweed beds support more juvenile reef fish than seagrass beds in a south-western Atlantic tropical seascape. Estuar Coast Shelf Sci 196:97-108. https://doi.org/10.1016/j.ecss.2017.06.041

Ellison J (1994) Climate change and sea level rise impacts on mangrove ecosystems. In: Pernetta J, Leemans R, Elder D et al (eds) Impacts of climate change on ecosystems and species. IUCN, Gland, pp 11-30

Ewel KC, Twilley RR, Ong JE (1998) Different kinds of mangrove forests provide different goods and services. Glob Ecol Biogeogr Lett 7:83-94. https://doi.org/10.2307/2997700

Fabricius KE (2005) Effects of terrestrial runoff on the ecology of corals and coral reefs: review and synthesis. Mar Pollut Bull 50:125146. https://doi.org/10.1016/j.marpolbul.2004.11.028

Fabricius KE, Okaji K, De'ath G (2010) Three lines of evidence to link outbreaks of the crown-of-thorns seastar Acanthaster planci to the release of larval food limitation. Coral Reefs 29:593-605. https:// doi.org/10.1007/s00338-010-0628-Z

Fabricius KE, Langdon C, Uthicke S et al (2011) Losers and winners in coral reefs acclimatized to elevated carbon dioxide concentrations. Nat Clim Chang 1:165-169. https://doi.org/10.1038/nclimate1122

Fabry VJ, Seibel BA, Feely RA et al (2008) Impacts of ocean acidification on marine fauna and ecosystem processes. ICES J Mar Sci $65: 414-432$

Falkenberg LJ, Russell BD, Connell SD (2013) Future herbivory: the indirect effects of enriched $\mathrm{CO}_{2}$ may rival its direct effects. Mar Ecol Prog Ser 492:85-95. https://doi.org/10.3354/meps10491

FAO (2016a) World fertilizer trends and outlook to 2019. FAO, Rome

FAO (2016b) The state of world fisheries and aquaculture. Contributing to food security and nutrition for all. FAO, Rome

Findlay HS, Kendall MA, Spicer JI et al (2010) Post-larval development of two intertidal barnacles at elevated $\mathrm{CO}_{2}$ and temperature. Mar Biol 157:725-735. https://doi.org/10.1007/s00227-009-1356-1

Flindt MR, Pardal MÂ, Lillebø AI et al (1999) Nutrient cycling and plant dynamics in estuaries : a brief review. Acta Oecol 20:237-248

Frankignoulle M, Distèche A (1984) $\mathrm{CO}_{2}$ chemistry in the water column above a Posidonia seagrass bed and related air-sea exchanges. Oceanol Acta 7:209-219

Franklin HB (2007) The most important fish in the sea: menhaden and America. Island Press, Washington, DC

Friess DA, Krauss KW, Horstman EM et al (2012) Are all intertidal wetlands naturally created equal? Bottlenecks, thresholds and 
knowledge gaps to mangrove and saltmarsh ecosystems. Biol Rev 87:346-366. https://doi.org/10.1111/j.1469-185X.2011.00198.x

Garrard SL, Gambi MC, Scipione MB et al (2014) Indirect effects may buffer negative responses of seagrass invertebrate communities to ocean acidification. J Exp Mar Biol Ecol 461:31-38. https://doi. org/10.1016/j.jembe.2014.07.011

Gaylord B, Kroeker KJ, Sunday JM et al (2015) Ocean acidification through the lens of ecological theory. Ecology 96:3-15. https://doi. org/10.1890/14-0802.1

Gazeau F, Parker LM, Comeau S et al (2013) Impacts of ocean acidification on marine shelled molluscs. Mar Biol 160:2207-2245. https://doi.org/10.1007/s00227-013-2219-3

Gegner HM, Ziegler M, Rädecker N et al (2017) High salinity conveys thermotolerance in the coral model Aiptasia. Biol Open 6:19431948. https://doi.org/10.1242/bio.028878

Gerber LR, Mancha-Cisneros MDM, O'Connor M et al (2014) Climate change impacts on connectivity in the ocean: implications for conservation. Ecosphere 5:1-18. https://doi.org/10.1890/ES13-00336.1

Gillis LG, Bouma TJ, Jones CG et al (2014) Potential for landscapescale positive interactions among tropical marine ecosystems. Mar Ecol Prog Ser 503:289-303. https://doi.org/10.3354/meps10716

Gilman E, van Lavieren J, Ellison V (2006) Pacific Island mangroves in a changing climate and rising sea. United Nations Environment Programme, Regional Seas Programme, Nairobi

Gilman EL, Ellison J, Duke NC et al (2008) Threats to mangroves from climate change and adaptation options: a review. Aquat Bot $89: 237-250$

Gladstone W (2008) Towards conservation of a globally significant ecosystem: the Red Sea and Gulf of Aden. Aquat Conserv Mar Freshwat Ecosyst 18:1-5

Gnanadesikan A, Stouffer RJ (2006) Diagnosing atmosphere-ocean general circulation model errors relevant to the terrestrial biosphere using the Köppen climate classification. Geophys Res Lett 33:L22701. https://doi.org/10.1029/2006GL028098

Godoy MDP, De Lacerda LD (2015) Mangroves response to climate change: a review of recent findings on mangrove extension and distribution. An Acad Bras Cienc Ann Braz Acad Sci 87:651-667. https://doi.org/10.1590/0001-3765201520150055

Golbuu Y, Victor S, Wolanski E et al (2003) Trapping of fine sediment in a semi-enclosed bay, Palau, Micronesia. Estuar Coast Shelf Sci 57:941-949. https://doi.org/10.1016/S0272-7714(02)00424-9

Granek EF, Compton JE, Phillips DL (2009) Mangrove-exported nutrient incorporation by sessile coral reef invertebrates. Ecosystems 12:462-472. https://doi.org/10.1007/s10021-009-9235-7

Green EP, Short FT (2003) World atlas of seagrasses. Prepared by the UNEP World Conservation Monitoring Centre. University of California Press, Berkeley

Grober-Dunsmore R, Pittman SJ, Caldow C et al (2009) A landscape ecology approach for the study of ecological connectivity across tropical marine seascapes. In: Nagelkerken I (ed) Ecological connectivity among tropical coastal ecosystems. Springer, Dordrecht, pp 493-530

Guannel G, Arkema K, Ruggiero P et al (2016) The power of three: coral reefs, seagrasses and mangroves protect coastal regions and increase their resilience. PLoS ONE 11:e0158094. https://doi. org/10.1371/journal.pone.0158094

Guinotte JM, Fabry VJ (2008) Ocean acidification and its potential effects on marine ecosystems. Ann NY Acad Sci 1134:320-342

Hall-Spencer JM, Rodolfo-Metalpa R, Martin S et al (2008) Volcanic carbon dioxide vents show ecosystem effects of ocean acidification. Nature 454:96-99. https://doi.org/10.1038/nature07051

Halpern BS, Walbridge S, Selkoe KA et al (2008) A global map of human impact on marine ecosystems. Science 319:948-952. https:// doi.org/10.1126/science. 1149345

Hamilton LS, Snedaker SC (1984) Handbook for mangrove area management. East-West Environment and Policy Institute, Honolulu
Harley CDG, Anderson KM, Demes KW et al (2012) Effects of climate change on global seaweed communities. J Phycol 48:1064-1078. https://doi.org/10.1111/j.1529-8817.2012.01224.x

Heck KL, Carruthers TJB, Duarte CM et al (2008) Trophic transfers from seagrass meadows subsidize diverse marine and terrestrial consumers. Ecosystems 11:1198-1210. https://doi.org/10.1007/ s10021-008-9155-y

Heenan A, Williams ID (2013) Monitoring herbivorous fishes as indicators of coral reef resilience in American Samoa. PLoS ONE 8:e79604. https://doi.org/10.1371/journal.pone.0079604

Henderson CJ, Gilby BL, Lee SY et al (2017) Contrasting effects of habitat complexity and connectivity on biodiversity in seagrass meadows. Mar Biol 164:117. https://doi.org/10.1007/ s00227-017-3149-2

Hendriks IE, Olsen YS, Ramajo L et al (2014) Photosynthetic activity buffers ocean acidification in seagrass meadows. Biogeosciences 11:333-346. https://doi.org/10.5194/bg-11-333-2014

Hendriks IE, Duarte CM, Olsen YS et al (2015) Biological mechanisms supporting adaptation to ocean acidification in coastal ecosystems. Estuar Coast Shelf Sci 152:A1-A8. https://doi.org/10.1016/j. ecss.2014.07.019

Hepburn CD, Pritchard DW, Cornwall CE et al (2011) Diversity of carbon use strategies in a kelp forest community: implications for a high $\mathrm{CO}_{2}$ ocean. Glob Chang Biol 17:2488-2497. https://doi. org/10.1111/j.1365-2486.2011.02411.x

Herbeck LS, Sollich M, Unger D et al (2014) Impact of pond aquaculture effluents on seagrass performance in NE Hainan, tropical China. Mar Pollut Bull 85:190-203. https://doi.org/10.1016/j. marpolbul.2014.05.050

Hoegh-Guldberg O (2014) Tropical marine ecosystems. In: Lindenmayer D, Morton S, Dovers S (eds) Ten commitments revisited: securing Australia's future environment. CSIRO Publishing, Collingwood, pp 59-70

Hoegh-Guldberg O, Bruno JF (2010) The impact of climate change on the world's marine ecosystems. Science 328:1523-1528. https:// doi.org/10.1126/science. 1189930

Hoegh-Guldberg O, Mumby PJ, Hooten AJ et al (2007) Coral reefs under rapid climate change and ocean acidification. Science 318:1737-1742

Howells EJ, Abrego D, Meyer E et al (2016) Host adaptation and unexpected symbiont partners enable reef-building corals to tolerate extreme temperatures. Glob Chang Biol 22:2702-2714. https://doi. org/10.1111/gcb. 13250

Hughes TP (1994) Catastrophes, phase shifts, and large-scale degradation of a Caribbean coral reef. Science 265:1547-1551. https://doi. org/10.1126/science.265.5178.1547

Invers O, Romero J, Pérez M (1997) Effects of pH on seagrass photosynthesis: a laboratory and field assessment. Aquat Bot 59:185-194. https://doi.org/10.1016/S0304-3770(97)00072-7

IPCC (2013) Climate change 2013 - the physical science basis. Contribution of working group I to the fifth assessment report of the intergovernmental panel on climate change. Cambridge University Press, Cambridge, New York. https://doi.org/10.1017/ CBO9781107415324

Jackson JBC, Kirby MX, Berger WH et al (2001) Historical overfishing and the recent collapse of coastal ecosystems. Science 293:629-637

Jennerjahn TC (2012) Biogeochemical response of tropical coastal systems to present and past environmental change. Earth Sci Rev 114:19-41

Jennerjahn TC, Ittekkot V (2002) Relevance of mangroves for the production and deposition of organic matter along tropical continental margins. Naturwissenschaften 89:23-30

Kathiresan K (2008) Threats to mangroves - degradation and destruction of mangroves. Centre of Advanced Study in Marine Biology. Annamalai University 
Kathiresan K, Bingham BL (2001) Biology of mangroves and mangrove ecosystems. Adv Mar Biol 40:81-251. https://doi.org/10.1016/ S0065-2881(01)40003-4

Kathiresan K, Rajendran N (2005) Coastal mangrove forests mitigated tsunami. Estuar Coast Shelf Sci 65:601-606. https://doi. org/10.1016/j.ecss.2005.06.022

Kenkel CD, Meyer E, Matz MV (2013) Gene expression under chronic heat stress in populations of the mustard hill coral (Porites astreoides) from different thermal environments. Mol Ecol 22:43224334. https://doi.org/10.1111/mec.12390

Kennedy EV, Perry CT, Halloran PR et al (2013) Avoiding coral reef functional collapse requires local and global action. Curr Biol 23:912-918. https://doi.org/10.1016/j.cub.2013.04.020

Khan S, Larrosa C (2008) Economic values of coral reefs, mangroves, and seagrasses: a global compilation. Center for Applied Biodiversity Science, Conservation International, Arlington

Kitheka JU (1997) Coastal tidally-driven circulation and the role of water exchange in the linkage beween tropical coastal ecosystems. Estuar Coast Shelf Sci 45:177-187. https://doi.org/10.1006/ ecss.1996.0189

Kleypas JA, Langdon C, Phinney JT et al (2006) Coral reefs and changing seawater carbonate chemistry. In: Phinney JT, Hoegh-Guldberg $\mathrm{O}$, Kleypas $\mathrm{J}$ et al (eds) Coral reefs and climate change: science and management. American Geophysical Union, Washington, DC, pp 73-110

Knutson TR, McBride JL, Chan J et al (2010) Tropical cyclones and climate change. Nat Geosci 3:157-163

Koch MS, Schopmeyer S, Kyhn-Hansen C et al (2007) Synergistic effects of high temperature and sulfide on tropical seagrass J Exp Mar Biol Ecol 341:91-101. https://doi.org/10.1016/j. jembe.2006.10.004

Koch EW, Barbier EB, Silliman BR et al (2009) Non-linearity in ecosystem services: temporal and spatial variability in coastal protection. Front Ecol Environ 7:29-37

Koch M, Bowes G, Ross C et al (2013) Climate change and ocean acidification effects on seagrasses and marine macroalgae. Glob Chang Biol 19:103-132

Krauss KW, McKee KL, Lovelock CE et al (2014) How mangrove forests adjust to rising sea level. New Phytol 202:19-34. https://doi. org/10.1111/nph.12605

Kroeker KJ, Kordas RL, Crim RN et al (2010) Meta-analysis reveals negative yet variable effects of ocean acidification on marine organisms. Ecol Lett 13:1419-1434

Kroeker KJ, Kordas RL, Crim R et al (2013) Impacts of ocean acidification on marine organisms: quantifying sensitivities and interaction with warming. Glob Chang Biol 19:1884-1896. https://doi. org/10.1111/gcb.12179

Kurihara $\mathrm{H}$ (2008) Effects of $\mathrm{CO}_{2}$-driven ocean acidification on the early developmental stages of invertebrates. Mar Ecol Prog Ser 373:275-284

Kvitt H, Rosenfeld H, Zandbank K et al (2011) Regulation of apoptotic pathways by Stylophora pistillata (anthozoa, pocilloporidae) to survive thermal stress and bleaching. PLoS ONE 6:e28665. https://doi. org/10.1371/journal.pone.0028665

Lamb JB, van de Water JAJM, Bourne DG et al (2017) Seagrass ecosystems reduce exposure to bacterial pathogens of humans, fishes, and invertebrates. Science 355:731-733. https://doi.org/10.1126/ science.aal1956

Lamy T, Legendre P, Chancerelle Y et al (2015) Understanding the spatio-temporal response of coral reef fish communities to natural disturbances: insights from beta-diversity decomposition. PLoS ONE 10:e0138696. https://doi.org/10.1371/journal.pone.0138696

Langdon C, Atkinson MJ (2005) Effect of elevated $\mathrm{pCO}_{2}$ on photosynthesis and calcification of corals and interactions with seasonal change in temperature/irradiance and nutrient enrichment. J Geophys Res 110:C09S07. https://doi. org/10.1029/2004JC002576
Lapointe BE (1997) Nutrient thresholds for bottom-up control of macroalgal blooms on coral reefs in Jamaica and southeast Florida. Limnol Oceanogr 42:1119-1131. https://doi.org/10.4319/ lo.1997.42.5

Le Quéré C, Andres RJ, Boden T et al (2013) The global carbon budget 1959-2011. Earth Syst Sci Data 5:165-185. https://doi.org/10.5194/ essd-5-165-2013

Lee KS, Park SR, Kim YK (2007) Effects of irradiance, temperature, and nutrients on growth dynamics of seagrasses: a review. J Exp Mar Biol Ecol 350:144-175

Lovelock CE, Cahoon DR, Friess DA et al (2015) The vulnerability of Indo-Pacific mangrove forests to sea-level rise. Nature 526:559563. https://doi.org/10.1038/nature 15538

Luo J, Serafy JE, Sponaugle S et al (2009) Movement of gray snapper Lutjanus griseus among subtropical seagrass, mangrove, and coral reef habitats. Mar Ecol Prog Ser 380:255-269. https://doi. org/10.3354/meps07911

Magris RA, Heron SF, Pressey RL (2015) Conservation planning for coral reefs accounting for climate warming disturbances. PLoS ONE 10:e0140828. https://doi.org/10.1371/journal.pone.0140828

Manson FJ, Loneragan NR, Harch BD et al (2005) A broad-scale analysis of links between coastal fisheries production and mangrove extent: a case-study for northeastern Australia. Fish Res 74:69-85. https://doi.org/10.1016/j.fishres.2005.04.001

Marean CW, Bar-Matthews M, Bernatchez J et al (2007) Early human use of marine resources and pigment in South Africa during the Middle Pleistocene. Nature 449:905-908. https://doi.org/10.1038/ nature 06204

Matson PA, Parton WJ, Power AG et al (1997) Agricultural intensification and ecosystem properties. Science 227:504-509. https://doi. org/10.1126/science.277.5325.504

Maxwell PS, Eklöf JS, van Katwijk MM et al (2017) The fundamental role of ecological feedback mechanisms for the adaptive management of seagrass ecosystems - a review. Biol Rev 92:1521-1538. https://doi.org/10.1111/brv.12294

McAllister DE (1995) Status of the World Ocean and its biodiversity. Sea Wind 9:1-72

McCook LJ (1999) Macroalgae, nutrients and phase shifts on coral reefs: scientific issues and management consequences for the Great Barrier Reef. Coral Reefs 367:357-367

McCormick MI, Watson SA, Munday PL (2013) Ocean acidification reverses competition for space as habitats degrade. Sci Rep 3:3280. https://doi.org/10.1038/srep03280

McCulloch M, Falter J, Trotter J et al (2012) Coral resilience to ocean acidification and global warming through $\mathrm{pH}$ up-regulation. Nat Clim Chang 2:623-627. https://doi.org/10.1038/nclimate1473

McGlathery KJ (2001) Macroalgal blooms contribute to the decline of seagrass in nutrient-enriched coastal waters. J Phycol 37:453-456. https://doi.org/10.1046/j.1529-8817.2001.037004453.x

McGlathery KJ, Sundbäck K, Anderson IC (2007) Eutrophication in shallow coastal bays and lagoons: the role of plants in the coastal filter. Mar Ecol Prog Ser 348:1-18. https://doi.org/10.3354/ meps07132

McIvor A, Spencer T, Möller I et al (2012) Storm surge reduction by mangroves. Natural coastal protection series: report 2. Cambridge Coastal Research Unit working paper 41. Published by The Nature Conservancy and Wetlands International

Milazzo M, Rodolfo-Metalpa R, Chan VBS et al (2014) Ocean acidification impairs vermetid reef recruitment. Sci Rep 4:4189. https:// doi.org/10.1038/srep04189

Miller AW, Reynolds AC, Sobrino C et al (2009) Shellfish face uncertain future in high $\mathrm{CO}_{2}$ world: influence of acidification on oyster larvae calcification and growth in estuaries. PLoS ONE 4:e5661. https://doi.org/10.1371/journal.pone.0005661

Moberg F, Folke C (1999) Ecological goods and services of coral reef ecosystems. Ecol Econ 29:215-233. https://doi.org/10.1016/ S0921-8009(99)00009-9 
Morell JM, Corredor JE (1993) Sediment nitrogen trapping in a mangrove lagoon. Estuar Coast Shelf Sci 37:203-212. https://doi. org/10.1006/ecss.1993.1051

Mumby PJ (2006) The impact of exploiting grazers (Scaridae) on the dynamics of caribbean coral reefs. Ecol Appl 16:747-769. https:// doi.org/10.1890/1051-0761(2006)016[0747:TIOEGS]2.0.CO;2

Mumby PJ, Edwards AJ, Arias-González JE et al (2004) Mangroves enhance the biomass of coral reef fish communities in the Caribbean. Nature 427:533-536. https://doi.org/10.1038/nature02286

Mumby PJ, Hastings A, Edwards HJ (2007) Thresholds and the resilience of Caribbean coral reefs. Nature 450:98-101. https://doi. org/10.1038/nature06252

Mumby PJ, Iglesias-Prieto R, Hooten AJ et al (2011) Revisiting climate thresholds and ecosystem collapse. Front Ecol Environ 9:94-96

Munday PL, Crawley NE, Nilsson GE (2009) Interacting effects of elevated temperature and ocean acidification on the aerobic performance of coral reef fishes. Mar Ecol Prog Ser 388:235-242. https:// doi.org/10.3354/meps08137

Nagelkerken I (2009) Ecological connectivity among tropical coastal ecosystems. Springer, Dordrecht

Newton K, Côté IM, Pilling GM et al (2007) Current and future sustainability of island coral reef fisheries. Curr Biol 17:655-658. https:// doi.org/10.1016/j.cub.2007.02.054

O'Connor S, Ono R, Clarkson C (2011) Pelagic fishing at 42,000 years before the present and the maritime skills of modern humans. Science 334:1117-1121. https://doi.org/10.1126/science.1207703

Odum EP (1968) Energy flow in ecosystems: a historical review. Integr Comp Biol 8:11-18. https://doi.org/10.1093/icb/8.1.11

Odum WE, Heald EJ (1972) Trophic analyses of an estuarine mangrove community. Bull Mar Sci 22:671-738

Ogden JC (1980) Faunal relationships in Caribbean seagrass beds. In: Phillips RC, CP MR (eds) Handbook of seagrass biologi: an ecosystem perspective. Garland STPM Press, New York, pp 173-198

Ormond R (1987) Conservation and management. In: Edwards A, Head S (eds) Key environments: Red Sea. Pergamon Press, Oxford, pp 405-423

Palacios S, Zimmerman R (2007) Response of eelgrass Zostera marina to $\mathrm{CO}_{2}$ enrichment: possible impacts of climate change and potential for remediation of coastal habitats. Mar Ecol Prog Ser 344:113. https://doi.org/10.3354/meps07084

Pandolfi JM, Connolly SR, Marshall DJ et al (2011) Projecting coral reef futures under global warming and ocean acidification. Science 333:418-422. https://doi.org/10.1126/science.1204794

Parrish JD (1989) Fish communities of interacting shallow-water habitats in tropical oceanic regions. Mar Ecol Prog Ser 58:143-160. https://doi.org/10.3354/meps058143

Pauly D, Christensen V, Guénette S et al (2002) Towards sustainability in world fisheries. Nature 418:689-695. https://doi.org/10.1038/ nature 01017

Payri CE, Naim O (1982) Variations entre 1971 et 1980 de la biomasse et de la composition des populations de macroalgues sur le recif corallien de Tiahura (le de Moorea, Polynesie francaise). Cryptogam Algol 3:229-240

Pernetta JC (1993) Mangrove forests, climate change and sea level rise: hydrological influences on community structure and survival, with examples from the Indo-West Pacific. IUCN, Gland

Plaisance L, Caley MJ, Brainard RE et al (2011) The diversity of coral reefs: what are we missing? PLoS ONE 6:e25026. https://doi. org/10.1371/journal.pone.0025026

Pörtner HO (2008) Ecosystem effects of ocean acidification in times of ocean warming: a physiologist's view. Mar Ecol Prog Ser 373:203-217

Putnam HM, Stat M, Pochon X et al (2012) Endosymbiotic flexibility associates with environmental sensitivity in scleractinian corals. Proc R Soc B 279:4352-4361. https://doi.org/10.1098/ rspb.2012.1454
Ramos AA, Inoue Y, Ohde S (2004) Metal contents in Porites corals: anthropogenic input of river run-off into a coral reef from an urbanized area, Okinawa. Mar Pollut Bull 48:281-294. https://doi. org/10.1016/j.marpolbul.2003.08.003

Raven J, Caldeira K et al (2005) Ocean acidification due to increasing atmospheric carbon dioxide. R Soc Rep 12:1-68

Ricard D, Minto C, Jensen OP et al (2012) Examining the knowledge base and status of commercially exploited marine species with the RAM legacy stock assessment database. Fish Fish 13:380-398. https://doi.org/10.1111/j.1467-2979.2011.00435.x

Richier S, Rodriguez-Lanetty M, Schnitzler CE et al (2008) Response of the symbiotic cnidarian Anthopleura elegantissima transcriptome to temperature and UV increase. Comp Biochem Physiol D 3:283289. https://doi.org/10.1016/j.cbd.2008.08.001

Riser SC, Freeland HJ, Roemmich D et al (2016) Fifteen years of ocean observations with the global argo array. Nat Clim Chang 6:145-153

Robertson AI, Duke NC (1987) Mangroves as nursery sites: comparisons of the abundance and species composition of fish and crustaceans in mangroves and other nearshore habitats in tropical Australia. Mar Biol 96:193-205. https://doi.org/10.1007/ BF00427019

Robinson KL, Ruzicka JJ, Hernandez FJ et al (2015) Evaluating energy flows through jellyfish and gulf menhaden (Brevoortia patronus) and the effects of fishing on the northern Gulf of Mexico ecosystem. ICES J Mar Sci 72:2301-2312. https://doi.org/10.1093/icesjms/ fsv088

Rossoll D, Bermúdez R, Hauss H et al (2012) Ocean acidificationinduced food quality deterioration constrains trophic transfer. PLoS ONE 7:e34737. https://doi.org/10.1371/journal.pone.0034737

Russell BD, Thompson JAI, Falkenberg LJ et al (2009) Synergistic effects of climate change and local stressors: $\mathrm{CO}_{2}$ and nutrientdriven change in subtidal rocky habitats. Glob Chang Biol 15:21532162. https://doi.org/10.1111/j.1365-2486.2009.01886.x

Sale PF, Agardy T, Ainsworth CH et al (2014) Transforming management of tropical coastal seas to cope with challenges of the 21st century. Mar Pollut Bull 85:8-23. https://doi.org/10.1016/j. marpolbul.2014.06.005

Sampayo EM, Ridgway T, Bongaerts P et al (2008) Bleaching susceptibility and mortality of corals are determined by fine-scale differences in symbiont type. Proc Natl Acad Sci U S A 105:1044410449. https://doi.org/10.1073/pnas.0708049105

Saunders MI, Leon JX, Callaghan DP et al (2014) Interdependency of tropical marine ecosystems in response to climate change. Nat Clim Chang 4:724-729. https://doi.org/10.1038/NCLIMATE2274

Scartazza A, Moscatello S, Gavrichkova O et al (2017) Carbon and nitrogen allocation strategy in Posidonia oceanica is altered by seawater acidification. Sci Total Environ 607-608:954-964. https://doi. org/10.1016/j.scitotenv.2017.06.084

Schaffelke B, Klumpp DW (1998) Short-term nutrient pulses enhance growth and photosynthesis of the coral reef macroalga Sargassum baccularia. Mar Ecol Prog Ser 170:95-105. https://doi.org/10.3354/ meps170095

Schaffelke B, Mellors J, Duke NC (2005) Water quality in the Great Barrier Reef region: responses of mangrove, seagrass and macroalgal communities. Mar Pollut Bull 51:279-296. https://doi. org/10.1016/j.marpolbul.2004.10.025

Short FT, Neckles HA (1999) The effects of global climate change on seagrasses. Aquat Bot 63:169-196. https://doi.org/10.1016/ S0304-3770(98)00117-X

Short F, Carruthers T, Dennison W et al (2007) Global seagrass distribution and diversity: a bioregional model. J Exp Mar Biol Ecol 350:3-20. https://doi.org/10.1016/j.jembe.2007.06.012

Short FT, Polidoro B, Livingstone SR et al (2011) Extinction risk assessment of the world's seagrass species. Biol Conserv 144:19611971. https://doi.org/10.1016/j.biocon.2011.04.010

Short FT, Coles R, Fortes MD et al (2014) Monitoring in the Western Pacific region shows evidence of seagrass decline in line with global 
trends. Mar Pollut Bull 83:408-416. https://doi.org/10.1016/j. marpolbul.2014.03.036

Singh G, Ramanathan AL, Prasad MBK (2005) Nutrient cycling in mangrove ecosystem: a brief overview. Int $\mathrm{J}$ Ecol Environ Sci $31: 231-244$

Spalding MD, Green EP, Ravilious C (2001) World atlas of coral reefs. University of California Press/UNEP-WCMC, Berkeley

Spalding M, Kainuma M, Collins L (2010) World atlas of mangroves. Earthscan, London

Stewart HL (2006) Morphological variation and phenotypic plasticity of buoyancy in the macroalga Turbinaria ornata across a barrier reef Mar Biol 149:721-730. https://doi.org/10.1007/s00227-005-0186-z

Stewart HL (2008) The role of spatial and ontogenetic morphological variation in the expansion of the geographic range of the tropical brown alga, Turbinaria ornata. Integr Comp Biol 48:713-719. https://doi.org/10.1093/icb/icn028

Stone R (2007) Ecology. A world without corals? Science 316:678681. https://doi.org/10.1126/science.316.5825.678

Swindells KL, Murdoch RJ, Bazen WD et al (2017) Habitat configuration alters herbivory across the tropical seascape. Front Mar Sci 4:48. https://doi.org/10.3389/fmars.2017.00048

Talmage SC, Gobler CJ (2010) Effects of past, present, and future ocean carbon dioxide concentrations on the growth and survival of larval shellfish. Proc Natl Acad Sci U S A 107:17246-17251. https://doi. org/10.1073/pnas.0913804107

Tambutté E, Venn AA, Holcomb M et al (2015) Morphological plasticity of the coral skeleton under $\mathrm{CO}_{2}$-driven seawater acidification. Nat Commun 6:7368. https://doi.org/10.1038/ncomms8368

Tomlinson PB (2016) The botany of mangroves. Cambridge University Press, Cambridge

Trenberth KE (2005) Uncertainty in hurricanes and global warming. Science 308:1753-1754

Trenberth KE (2011) Changes in precipitation with climate change. Clim Res 47:123-138. https://doi.org/10.3354/cr00953

UNEP-WCMC (2006) In the front line: shoreline protection and other ecosystem services from mangroves and coral reefs. UNEPWCMC, Cambridge

Unsworth RKF, De León PS, Garrard SL et al (2008) High connectivity of Indo-Pacific seagrass fish assemblages with mangrove and coral reef habitats. Mar Ecol Prog Ser 353:213-224. https://doi. org/10.3354/meps07199

Unsworth RKF, Collier CJ, Henderson GM et al (2012) Tropical seagrass meadows modify seawater carbon chemistry: implications for coral reefs impacted by ocean acidification. Environ Res Lett 7:024026. https://doi.org/10.1088/1748-9326/7/2/024026

Valiela I, Cole ML (2002) Comparative evidence that salt marshes and mangroves may protect seagrass meadows from land-derived nitrogen loads. Ecosystems 5:92-102. https://doi.org/10.1007/ s10021-001-0058-4

Valiela I, Bowen JL, York JK (2001) Mangrove forests: one of the world's threatened major tropical environments. Bioscience 51:807-
815. https://doi.org/10.1641/0006-3568(2001)051[0807:MFOOTW 12.0.CO;2

van Oppen MJH, Oliver JK, Putnam HM et al (2015) Building coral reef resilience through assisted evolution. Proc Natl Acad Sci U S A 112:2307-2313. https://doi.org/10.1073/pnas.1422301112

van Tussenbroek BI, Hernández Arana HA, Rodríguez-Martínez RE et al (2017) Severe impacts of brown tides caused by Sargassum spp. on near-shore Caribbean seagrass communities. Mar Pollut Bull 122:272-281. https://doi.org/10.1016/j.marpolbul.2017.06.057

Vaughan DS, Shertzer KW, Smith JW (2007) Gulf menhaden (Brevoortia patronus) in the U.S. Gulf of Mexico: fishery characteristics and biological reference points for management. Fish Res 83:263-275. https://doi.org/10.1016/j.fishres.2006.10.002

Vermaat JE, Thampanya U (2006) Mangroves mitigate tsunami damage: a further response. Estuar Coast Shelf Sci 69:1-3. https://doi. org/10.1016/j.ecss.2006.04.019

Vitousek PM, Mooney HA, Lubchenco J et al (1997) Human domination of Earth's ecosystems. Science 277:494-499. https://doi. org/10.1126/science.277.5325.494

Ward RD, Friess DA, Day RH et al (2016) Impacts of climate change on mangrove ecosystems: a region by region overview. Ecosyst Heal Sustain 2:e01211. https://doi.org/10.1002/ehs2.1211

Waycott M, Duarte CM, Carruthers TJB et al (2009) Accelerating loss of seagrasses across the globe threatens coastal ecosystems. Proc Natl Acad Sci U S A 106:12377-12381. https://doi.org/10.1073/ pnas.0905620106

Wilkinson CR (1992) Coral reefs of the world are facing widespread devastation: can we prevent this through sustainable management practices? Proc Seventh Int Coral Reef Symp 1:11-21

Wilkinson C (2008) Status of coral reefs of the world: 2008. Global Coral Reef Monitoring Network and Reef and Rainforest Research Centre. The Australian Institute of Marine Science (AIMS), Townsville

Worm B, Barbier EB, Beaumont $\mathrm{N}$ et al (2006) Impacts of biodiversity loss on ocean ecosystem services. Science 314:787-790. https://doi. org/10.1126/science.1132294

Yellowlees D, Rees TAV, Leggat W (2008) Metabolic interactions between algal symbionts and invertebrate hosts. Plant Cell Environ 31:679-694

Yeragi SS, Yeragi SG (2014) Status, biodiversity and distribution of mangroves in South Konkan, Sindhudurg District, Maharashtra State India: an overview. Int J Life Sci 2:67-69

Zhou X (2017) An overview of recently published global aquaculture statistics. FAO Aquact Newslett 56:6-8

Zimmerman RC, Kohrs DG, Steller DL et al (1997) Impacts of $\mathrm{CO}_{2}$ enrichment on productivity and light requirements of eelgrass. Plant Physiol 115:599-607. https://doi.org/10.1104/pp.115.2.599

Zubia M, Andréfouët S, Payri CE (2015) Distribution and biomass evaluation of drifting brown algae from Moorea lagoon (French Polynesia) for eco-friendly agricultural use. J Appl Phycol 27:12771287. https://doi.org/10.1007/s10811-014-0400-9
Open Access This chapter is licensed under the terms of the Creative Commons Attribution 4.0 International License (http://creativecommons.org/licenses/by/4.0/), which permits use, sharing, adaptation, distribution and reproduction in any medium or format, as long as you give appropriate credit to the original author(s) and the source, provide a link to the Creative Commons license and indicate if changes were made.
The images or other third party material in this chapter are included in the chapter's Creative Commons license, unless indicated otherwise in a credit line to the material. If material is not included in the chapter's Creative Commons license and your intended use is not permitted by statutory regulation or exceeds the permitted use, you will need to obtain permission directly from the copyright holder. 